\title{
INFLUÊNCIA DO HIDRÓXIDO DE CÁLCIO E DO EDTA NA MARCAÇÃO DA INFILTRAÇÃO MARGINAL DE AZUL DE METILENO EM OBTURAÇÃO DE CANAIS RADICULARES
}

\section{EDUARDO NUNES}

Tese apresentada à Faculdade de Odontologia de Bauru, da Universidade de São Paulo, como parte dos requisitos para obtenção do grau de Doutor em Odontologia, área de Endodontia. 


\section{INFLUÊNCIA DO HIDRÓXIDO DE CÁLCIO E DO EDTA NA MARCAÇÃO DA INFILTRAÇÃO MARGINAL DE AZUL DE METILENO EM OBTURAÇÃO DE CANAIS RADICULARES}

\section{EDUARDO NUNES}

Tese apresentada à Faculdade de Odontologia de Bauru, da Universidade de São Paulo, como parte dos requisitos para obtenção do grau de Doutor em Odontologia, área de Endodontia.

(Edição Revista)

Orientador: Prof.Dr. Ivaldo Gomes de Moraes 


\begin{tabular}{|c|c|}
\hline \multirow[t]{3}{*}{ N922i } & $\begin{array}{l}\text { Nunes, Eduardo } \\
\text { Influência do hidróxido de cálcio e do EDTA } \\
\text { na marcação da infiltração marginal de azul de } \\
\text { metileno em obturação de canais radiculares / } \\
\text { /Eduardo Nunes. -- Bauru, } 1999 . \\
\quad 126 \text { p.: il.; } 31 \mathrm{~cm} \text {. }\end{array}$ \\
\hline & $\begin{array}{l}\text { Tese. (Doutorado) - Faculdade de Odontologia } \\
\text { de Bauru. USP. }\end{array}$ \\
\hline & Orientador: Prof.Dr. Ivaldo Gomes de Moraes \\
\hline
\end{tabular}

Autorizo reprodução total da referida Tese de Doutorado.

Eduardo Nunes

Autor 


\section{EDUARDO NUNES}

8 de julho de 1962

Nascimento

Serro-MG

$1982-1986$

Curso de graduação em Odontologia na Faculdade de Odontologia da Universidade Federal de Minas Gerais - Belo Horizonte.

1989

Curso de Especialização em Endodontia, na Faculdade de Odontologia de Bauru, da Universidade de São Paulo.

1991-1993

Curso de Pós-Graduação em nível de Mestrado, na Faculdade de Odontologia de Bauru, da Universidade de São Paulo.

1994-1999

Curso de Pós-Graduação em nível de Doutorado, na Faculdade de Odontologia de Bauru, da Universidade de São Paulo.

1999

Professor do curso de Especialização em Endodontia da Pontifícia Universidade Católica de Minas Gerais.

Associações

Associação Brasileira de Endodontia - Secção Minas Gerais.

Associação Brasileira de 
Odontologia - Secção de Minas Gerais. 
Já se disse que as grandes idéias vêm ao mundo mansamente, como pombas. Talvez, então, se ouvirmos com atenção, escutaremos, em meio ao estrépito de impérios e nações, um discreto bater de asas, o suave acordar da vida e da esperança. Alguns dirão que tal esperança jaz numa nação; outros num homem.

Eu creio, ao contrário, que ela é despertada, revivificada, alimentada por milhões de indivíduos solitários, cujos atos e trabalho, diariamente, negam as fronteiras e as implicações mais cruas da história.

Como resultado, brilha por um breve momento a verdade, sempre ameaçada, de que cada e todo homem, sobre a base de seus próprios sofrimentos e alegrias, constrói para todos. 
Aos meus pais, Enio e Candinha, pelo amor, carinho e constante apoio.

À Bete, Jú, Maria de Lourdes e Júnior, sempre presentes.

À Christiane, pois você é muito especial.

Dedico este trabalho. 
"A imortalidade de que se reveste a natureza humana, faz o homem sempre presente. Presente pela cultura que transmitiu, presente pela amizade que conquistou, presente pelo exemplo que legou, sempre presente, porque o homem foi educador."

\section{Agradecimento especial}

\section{Dr. Ivaldo Gomes de Moraes:}

$\grave{A}$ você, que não se limitou a teorias, transmitindo conhecimentos com todo o seu potencial, mostrando-se amigo e preocupado com meus interesses, o meu respeito, eterna gratidão e amizade.

Obrigado. 
Aos professores da Disciplina de Endodontia da FOB-USP,

\author{
Dr. Alceu Berbert, \\ Dr. Clovis Monteiro Bramante, \\ Dr. Ivaldo Gomes de Moraes, \\ Dr. Norberti Bernardineli \\ Dr. Roberto Brandão Garcia,
}

os meus sinceros agradecimentos. 


\section{Meus agradecimentos}

À Deus, pela sua constante presença.

Ao professor Marco Antonio Hungaro Duarte (Sal) pela atenção dedicada na execução estatística deste trabalho, $e$ especialmente pela sua amizade.

Ao professor Dr. Alceu Berbert pelas valiosas sugestões quando da realização deste trabalho.

Aos colegas de pós-graduação, João Ferlini Filho, Mauricio Santa Cecilia, Simone M. Galvão de Sousa, Fábio Berbert e Carlos Spironelli, pela agradável convivência.

À colega Luciana Viti Betti, pela participação no projeto piloto.

Aos professores Dr. Hennio Parreira Horta e Dr. Cândido Cardoso Miranda Neto, pelo constante apoio.

Aos funcionários da disciplina Endodontia, Edimauro, Suely, D. Neide e Cleide, pela amizade.

À Faculdade de Odontologia de Bauru, Universidade de São Paulo, na pessoa de seu Diretor Prof. Dr. Aymar Pavarini.

Ao Dr. Luiz Fernando Pegoraro, Presidente da Comissão de Pós-Graduação da FOB-USP, pelo apoio ao curso.

À CAPES/MEC, pelos recursos proporcionados.

Aos funcionários da biblioteca, Cybelle, Maria Helena, Valéria, Rita e Ademir, pela constante colaboração. 
Aos funcionários da pós-graduação da FOB-USP, pela atenção.

Aos amigos Carminha, Fernanda, Renata, Guilherme e Marlene, pelo carinho.

À Suely Regina Bettio, pelo esmero no trabalho de digitação.

À Irani, pela paciência.

Ao Salvador e André, pelos serviços de xerox. 


\section{Infinitamente mais}

Se você acredita que pode, poderá

porque vontade gera energia

$e$ a disposição de fazer

é o começo da obra já concluída

A descrença e o desânimo de hoje

é o combustível que alimenta

o fracasso e a derrota em todas as épocas

Os homens que aí estão

de uma forma ou de outra

são os mesmos que sempre aí estiveram

e que com todas as suas manobras

jamais conseguiram adiar por muito tempo

a marcha da humanidade

rumo a uma vida melhor

A crise que aí se encontra

servindo como justificativa

para a inércia de muitos

de uma forma ou de outra

sempre esteve presente

e nunca foi barreira

porque jamais faltarão caminhos

para quem se dispõe a andar

Trabalho éo nome da magia

todas as realizações

que remove obstáculos

O que se faz um pouco a cada dia

vale mais do que muito, feito em um dia só

Paciência e perseverança

é o segredo de toda conquista

Os tempos nunca parecerão difíceis

quando a gente sabe aonde quer ir

e para lá se dirige com fé, amor e audácia

Se a inteligência e a coragem

ditarem as suas ações

Se o coração guiar cada um dos seus passos

Se o Espírito a tudo presidir

então você pode acreditar que pode

porque somente o êxito será de fato

algo inevitável em sua vida

E você acreditando que pode,

poderemos

porque juntos somos 
Agradecimentos e Dedicatória

\section{Infinitamente mais!}

Geraldo Eustáquio de Souza 


\section{SUMÁRIO}

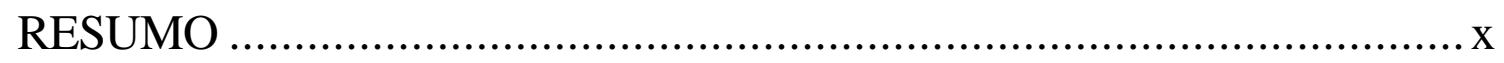

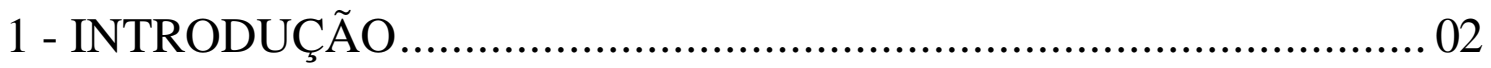

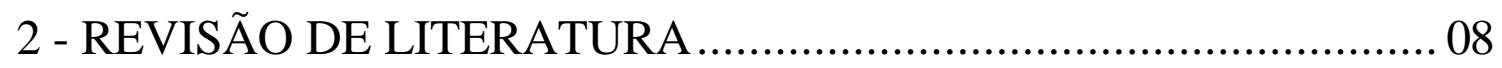

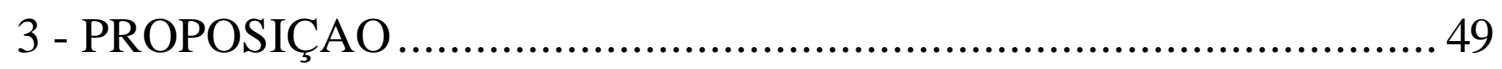

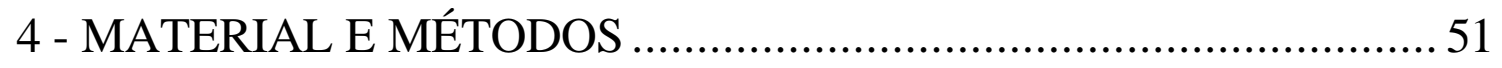

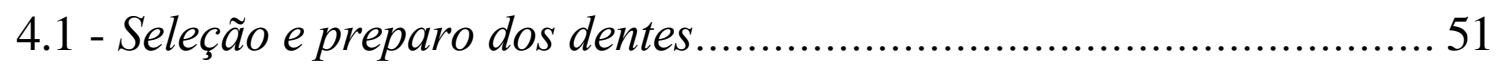

4.2 - Técnica de instrumentação........................................................ 52

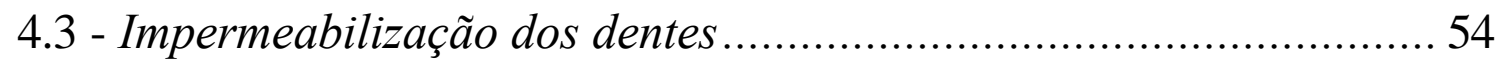

4.4 - Procedimentos comuns..................................................................... 58

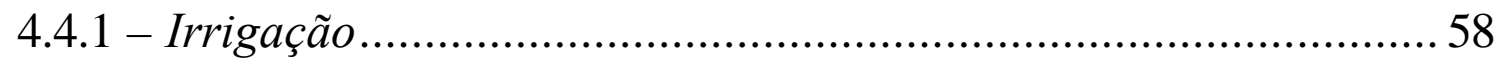

4.4.2 - Colocação da pasta de hidróxido de cálcio..................................58

4.4 .3 - Obturação dos canais................................................................. 59

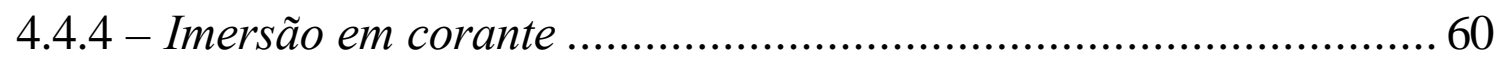

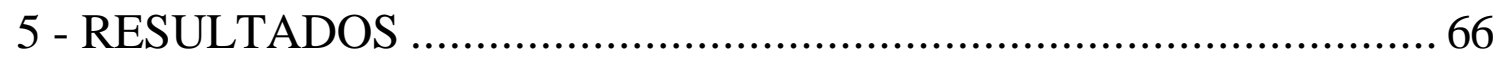

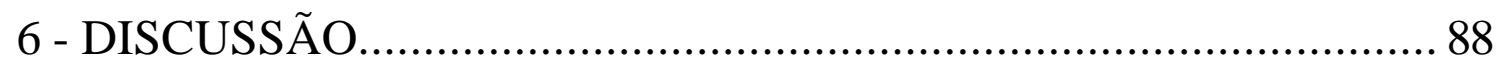

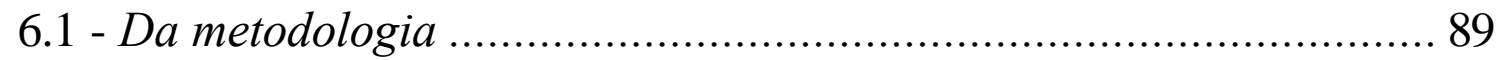

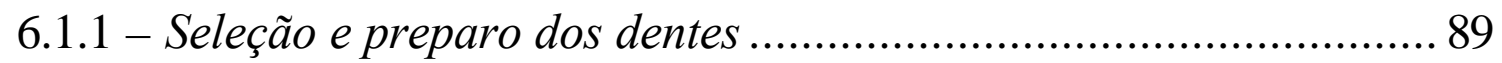

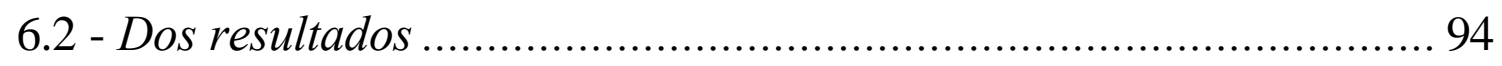

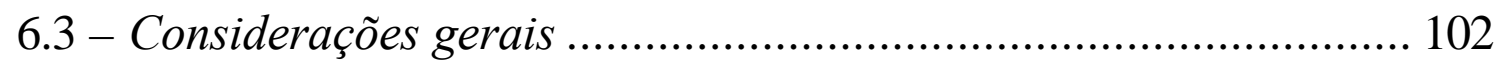

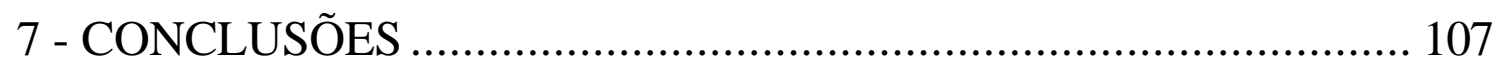

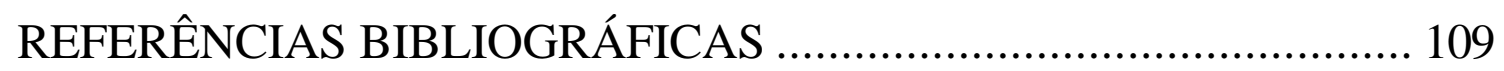

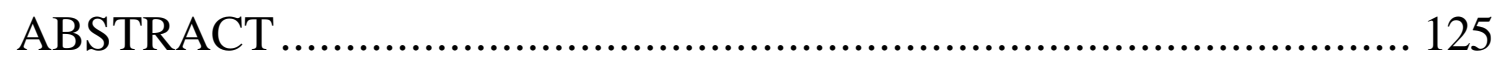




\section{RESUMO}

Com o objetivo de avaliar a influência do hidróxido de cálcio e do EDTA na marcação da infiltração marginal de corante azul de metileno a $2 \%$ em canais radiculares obturados pela técnica da condensação lateral, foram empregados 188 dentes incisivos centrais superiores humanos extraídos. Após serem instrumentados e impermeabilizados, foram divididos em 3 grupos de 60 elementos cada, sendo que outros 8 dentes foram utilizados como controle. Cada grupo foi dividido em 2 subgrupos, os quais, foram subdivididos em dois, totalizando 12 subgrupos com 15 elementos cada, dessa forma descritos: Grupo I - obturação imediata; em 30 dentes foi aplicado EDTA por 3 minutos antes da obturação; em 30 dentes a obturação foi feita sem a aplicação do EDTA; 30 dentes foram obturados com cimento de óxido de zinco e eugenol e 30 obturados com pasta de hidróxido de cálcio; Grupo II - aplicação de EDTA por 3 minutos e preenchimento de todos os canais com pasta de hidróxido de cálcio (curativo); em 30 dentes o EDTA foi reaplicado após a remoção do curativo, e nos outros 30 dentes não; 30 dentes foram obturados com cimento de óxido de zinco e eugenol e 30 obturados com pasta de hidróxido de cálcio; Grupo III - após a instrumentação, os canais foram preenchidos com pasta de hidróxido de cálcio (curativo) sem a aplicação prévia do EDTA; após a remoção do curativo, em 30 dentes o EDTA foi aplicado e em outros 30 não; 30 dentes foram obturados com cimento de óxido de zinco e eugenol e outros 30 
com pasta de hidróxido de cálcio. Posteriormente à imersão em azul de metileno a $2 \%$ por 72 horas, os dentes foram seccionados longitudinalmente e as infiltrações mensuradas com o emprego de um microscópio óptico munido de uma ocular micrometrada. Após serem empregados os testes estatísticos pertinentes, foram obtidas as seguintes conclusões: - em relação ao hidróxido de cálcio: como curativo e pasta obturadora, interfere estatisticamente na marcação da infiltração, diminuindo a sua magnitude; em relação ao EDTA: o seu emprego prévio ao curativo de hidróxido de cálcio, melhora o selamento das obturações com óxido de zinco e eugenol; o emprego antes e após o curativo, promove um aumento da infiltração em canais obturados com óxido de zinco e eugenol; em canais obturados com pasta de hidróxido de cálcio, o seu emprego não promove interferências estatisticamente significantes nos resultados. 


\section{1 - INTRODUÇÃO}




\section{1 - INTRODUÇÃO}

Para se obter sucesso no tratamento endodôntico é importante que se realize o desbridamento, a desinfecção, o alargamento e a completa obturação do sistema de canais radiculares ${ }^{44}$. Estas metas podem ser alcançadas por meio da instrumentação, ação dos líquidos irrigadores, medicação antiséptica intra-canal, bem como pelo preenchimento do mesmo com material obturador ${ }^{70}$. A obturação adequada e hermética do canal radicular em todo o seu volume e comprimento, dentro da estrutura dentária, usando-se de um selamento efetivo e biologicamente compatível, é o coroamento de um tratamento endodôntico bem realizado. Historicamente a obturação é considerada como o passo mais importante do tratamento e a sua má execução é causa da maioria dos insucessos em endodontia ${ }^{82}$. Entende-se como principais objetivos de uma boa obturação de canal: prevenir a formação de exsudato e sua percolação no interior do canal radicular; impedir a reinfecção por microrganismos que possam, enventualmente, ter permanecido após o preparo químicomecânico, e favorecer o processo biológico de cicatrização dos tecidos periapicais ${ }^{18}$. Obturações deficientes, especialmente no nível apical, podem oferecer condições para a presença de um meio de comunicação entre os tecidos periapicais e as paredes do canal radicular, podendo levar ao fracasso do tratamento ${ }^{44}$. Esta comunicação pode ocorrer geralmente pelas seguintes vias: forame apical, entre o material obturador e as paredes do canal; 
por difusão da superfície externa da raiz até o material obturador, via reabsorção cementária, canais laterais, secundários; ou mesmo até pelo acesso coronário. Assim sendo, o selamento hermético proporcionado pela completa obturação do sistema de canais radiculares é de fundamental importância no sucesso do tratamento endodôntico. Diante desta expectativa, desenvolveu-se uma série de trabalhos com o objetivo de observar que variáveis teriam influência na dimensão da infiltração marginal, objetivando reduzi-la à menor magnitude possível. Foram analisados a influência do material obturador ${ }^{1,3,7,20,26,36,47,53,75}$, da proporção pólíquido do cimento obturador ${ }^{41,53,61}$, das técnicas de obturação e inclusive, variáveis dentro das próprias técnicas ${ }^{11,53}$. Um arsenal muito grande de manobras e dispositivos obturadores especiais têm sido empregados nas técnicas de obturação, destacando-se os métodos que preconizam a termoplastificação da gutapercha ${ }^{10,20,47}$. Dentre estes, podemos destacar: a técnica de Mc Spadden, Híbrida de Tagger, Thermafil, Successfil, Sistema Obtura, Ultrafil, dentre outros. A despeito do surgimento cada vez mais freqüente de novas técnicas, a técnica de condensação lateral é a usualmente empregada pela maioria dos profissionais $3,7,10,20,26,34,35,37,41,42,53,54,69,70,75$. Além de ser uma técnica que não apresenta maiores dificuldades no seu manuseio, ela requer cimentos obturadores e instrumental convencionais. Outras vantagens que podem ser citadas: é que ela permite ter-se um maior controle longitudinal do que em outras técnicas, boa adaptação do material obturador æ̀s paredes dos canais, estabilidade dimensional positiva, facilidade de remoção quando 0 
retratamento se fizer necessário e praticidade para o preparo de espaço para retentores intra-radiculares. Em relação à eficiência desta técnica, no que diz respeito à infiltração marginal, guarda relação com diferentes fatores, tais como, variações introduzidas na própria técnica ou mesmo com o tipo de cimento obturador empregado, bem como manobras técnicas às quais os dentes são submetidos antes da obturação. Vários métodos têm sido usados para avaliar o selamento apical propiciado pela obturação do sistema de canais radiculares. Dentre estes, destacamos: teste de penetração de corantes ${ }^{1,10,17,20,35,37,40,42,49,53,54,69,70,71,75,76}$, estudos com isótopos radioativos ${ }^{4}$, testes para detectar a penetração de bactérias $^{4,26}$. Apesar de toda esta gama de opções, a preferência ao emprego de corantes é preponderante. A possível influência do emprego de determinadas substâncias utilizadas como curativo entre as sessões despertou interesse no que diz respeito à infiltração marginal do material selador temporário, ou mesmo do material obturador de canal. Os resultados de pesquisas, revelam que determinadas substâncias, não alteram a qualidade do selamento temporário, podendo mesmo até contribuir para diminuir a infiltração marginal de obturações de canal, como é o caso do otosporin e paramonoclorofenol canforado ${ }^{35}$.

Após a instrumentação dos canais, observa-se a presença do chamado magma dentinário ou smear-layer, que é uma camada amorfa de resíduos que recobre as paredes do canal, obstruindo os túbulos dentinários e criando uma interface entre o material obturador e a dentina $20,40,52,72$. É provável que este magma tenha um volume instável com o passar do tempo, devido ao seu 
alto conteúdo de água, o qual não se consegue eliminar, mesmo que se realize uma boa secagem do canal. O EDTA (ácido etileno diamino tetracético) é preconizado para remoção da smearlayer ${ }^{8,12,15,23,25,27,29,34,35,46,48,52,57,64,71,85}$, fato este que permitirá uma maior adesão ou embricamento do material obturador com a parede do canal, podendo o cimento inclusive penetrar no interior dos túbulos dentinários, propiciando um selamento mais efetivo $^{2,6,13,24,68,83}$.

Dentre as substâncias empregadas temporariamente no interior dos canais radiculares, destaca-se o hidróxido de cálcio $^{37,39,40,41,70,74}$, sendo o seu efeito antimicrobiano já bastante conhecido.

Em relação à possibilidade de que o hidróxido de cálcio, quando empregado como curativo entre sessões, deixe resíduos no interior do canal radicular, e possa exercer um efeito negativo quanto à qualidade do selamento da obturação de canal, tem despertado alguma preocupação em relação àtécnica para a sua remoção ${ }^{22,39,55,70}$. Alguns trabalhos demonstram que houve uma melhora na qualidade do selamento da obturação, tanto quanto empregado como curativo dentre sessões, como na utilização para obter um plug apical $\left.\right|^{9,37,39,41,70}$. Para justificar o mecanismo de ação do hidróxido de cálcio que possibilite um aumento da qualidade do selamento, várias hipóteses são sugeridas. Vão desde a diminuição da permeabilidade da dentina quando em contato com o hidróxido de cálcio $^{33}$, até mesmo àsua incorporação ao cimento obturador, causando por si só um decréscimo na permabilidade ${ }^{9,37}$. O hidróxido de cálcio penetrando nos túbulos dentinários, 
promoveria a sua oclusão, dificultando a penetração do corante ao redor das paredes do canal. Também é admitido a formação do carbonato de cálcio, o qual, no entanto é reabsorvível, podendo a longo prazo, favorecer a criação de espaços na interface obturação-parede do canal ${ }^{70}$.

Embora algumas pesquisas tenham mostrado que a utilização de curativo com hidróxido de cálcio diminuía a infiltração marginal de azul de metileno em obturações realizadas com cimentos $^{33,39,41,70}$ que comprovadamente, permitem grandes infiltrações, pairam dúvidas quanto à natureza desse selamento. Assim, ficam questionamentos se a infiltração realmente não ocorre ou se ela é impedida por alguma incompatibilidade entre corante/hidróxido de cálcio ou se a mesma acontece, porém a sua marcação é dificultada devido à possível impermeabilização dentinária, propiciada pelo hidróxido de cálcio. 


\section{2 - REVISÃO DE LITERATURA}




\section{2 - REVISÃO DE LITERATURA}

Em 1932, LUCAS $^{51}$, já destacava a importância de se conhecer a incompatibilidade entre os medicamentos, pois isto poderá acarretar modificações quando da sua utilização. Um grande número de produtos químicos promovem combinações entre sí, podendo resultar em novos compostos com propriedades diversas, inclusive, contrárias às desejadas. Em relação ao azul de metileno, é citado a sua incompatibilidade com azotato de prata, acetados de chumbo, cloreto de mercúrio, álcalis e sais em geral. Quanto a estes últimos, foi afirmado que estando muito diluídos, não promovem alteração em seus solutos; já em certa concentração precipitam o azul de metileno que redissolve, levando ao aumento do volume de água.

Em 1953, COOK; MARTIN ${ }^{16}$, discorrendo a respeito do azul de metileno, no tópico referente a incompatibilidades, descreveram que o mesmo se separa de suas soluções por salinização, não servindo para formar soluções a partir de sais minerais. Também é salientado que algumas substâncias promovem a sua precipitação, dentre as quais podemos destacar o permanganato de potássio, o bicromato de potássio, assim como as soluções fortes de hidróxido de potássio e sódio. Além do mais, destacaram que os agentes redutores destróem a cor azul de metileno. 
Em 1957, procurando aumentar a eficácia do preparo químico-mecânico dos canais radiculares, ÖSTBY ${ }^{65}$, preconizou o emprego do ácido etileno diamino tetracético (EDTA).

Incorporando hidróxido de sódio à solução com 15\% de sal dissódico de EDTA, teremos um pH 7,3 e a seguinte fórmula:

Sal dissódico de EDTA $17 \mathrm{~g}$

$5 \mathrm{~N}$ hidróxido de cálcio $.9,2$ $5 \mathrm{ml}$ Àgua destilada $100 \mathrm{ml}$.

Objetivando um aumento na atividade bactericida e redução da tensão superficial do EDTA, ÖSTBY ${ }^{66}$, em 1962, incorporou o cetavlon àfórmula. As duas soluções de EDTA, com ou sem o cetavlon, mostraram-se muito eficientes na limpeza dos canais e eliminação da smear-layer. Desta associação resultou o EDTAC, que além de reduzir o tempo de limpeza mecânica, não é irritante, cuja fórmula é a seguinte:

EDTA $143 \mathrm{~g}$

Cetavlon $0,84 \mathrm{ml}$

Água destilada. $1000 \mathrm{ml}$

$\mathrm{NaOH}$. .q.s.p

Com o objetivo de verificar a ação quelante do EDTAC, PATTERSON $^{67}$, em 1963, realizou uma pesquisa na qual foi constatado que na junção dentinocementária, a dureza da dentina era de 25 Knoop, valores que passavam para 60 a 80 na porção mediana da camada dentinária, até 40 nas proximidades do canal 
radicular. Após o emprego do EDTAC, por 24 horas, constatouse que havia um decréscimo da dureza destas regiões para 7 Knoop, além ser observado uma boa tolerância do tecido conjuntivo ao EDTA, fato este não ocorrido quando do emprego do EDTAC.

Utilizando-se de cortes de dentes humanos examinados ao microscópio, VON DER FEHR; ÖSTBY ${ }^{80}$, em 1963, estudaram o efeito do EDTAC e do ácido sulfúrico na dentina de condutos radiculares. A aplicação de EDTA resultou na desmineralização da dentina, chegando mesmo a remover completamente os sais minerais da camada interna da dentina. Já o ácido sulfúrico mostrou ter um efeito desmineralizador menor, porém penetrando mais profundamente na raiz, determinando uma aplicação menos segura do que o EDTAC.

Em 1973, HOLLAND et al. ${ }^{30}$ desenvolveram um trabalho para analisar a ação do sal sódico de EDTA em sucessivas trocas com intervalos curtos, bem como o estudo comparativo da ação de diferentes apresentações comerciais. Foram empregados dentes unirradiculados humanos extraídos, que tiveram os canais instrumentados, para favorecer a eliminação de detritos, remover a pré-dentina e padronizar os diâmetros. Após terem os seus forames vedados, os canais foram preenchidos com EDTA, EndoPrep, EDTAC, com sucessivas trocas. Após o tempo de experiência previsto, os dentes foram preparados e as lâminas coradas pelo método de Von Kossa. Os cortes histológicos foram 
analisados ao microscópio ótico e os halos de descalcificação medidos com o auxílio de uma ocular micrométrica. Pelos resultados obtidos foram tiradas algumas conclusões:

a) existem diferenças na velocidade de quelação entre os produtos testados;

b) a renovação constante dos produtos àbase de EDTA, no interior do canal, permite a obtenção de maior halo de descalcificação.

Com o objetivo de avaliar a eficiência do selamento marginal de obturações de canais realizadas pela técnica da condensação lateral, HOLLAND et al. ${ }^{31}$, em 1975, empregaram algumas variáveis. Foram usados 40 dentes humanos unirradiculados extraídos que tiveram os seus canais instrumentados e, posteriormente, obturados. Quando da obturação, optou-se por lubrificar ou não as paredes do canal com cimento obturador antes da inserção do cone principal e condensação com e sem o uso de pontas de Rhein. Após a obturação os dentes foram mantidos em câmara úmida e imersos em solução de 131 INa e em seguida foram tomadas autorradiografias que foram projetadas e as profundidades das infiltrações medidas e submedidas à análise estatística. Os resultados mostraram que a eficiência do selamento marginal foi superior quando se levou previamente cimento obturador ao interior dos canais.

Em 1975, MCCOMB; SMITH ${ }^{75,56}$ analisaram por meio de microscópica eletrônica de varredura, em canais de dentes 
humanos instrumentados, o efeito de distintas técnicas de instrumentação, com diferentes soluções irrigadoras. Pelos resultados observados, concluiu-se que:

a) após a instrumentação as paredes se apresentavam sujas e com resíduos;

b) uso do REDTA como irrigante ou no tratamento químico, produziu uma boa limpeza das paredes do conduto radicular, deixando-as livres da smear-layer e fragmentos superficiais.

Em 1976, MCCOMB; SMITH; BEAGRIE ${ }^{57}$ instrumentaram canais de dentes humanos in vivo, sendo estes, posteriormente, extraídos por razões diversas. Vários líquidos irrigadores foram empregados. Ao serem levados à avaliação ao microscópio eletrônico de varredura, as paredes dentinárias foram analisadas cuidadosamente. A ação dos líquidos irrigadores na limpeza da superfície dentinária demonstrou que o EDTA foi mais eficiente do que a água destilada, hipoclorito de sódio e solução de ácido poliacrílico. Os túbulos dentinários apresentavam-se visíveis, especialmente nos terços cervical e médio. A mesma observação não se fazia no terço apical e nos condutos estreitos e curvos.

Em 1976, WALTON ${ }^{82}$, utilizando dentes humanos que seriam extraídos por motivos protéticos ou ortodônticos, comparou a eficácia das técnicas de instrumentação convencional e telescópica, associadas a brocas Gates-Glidden. Na técnica convencional foi usado movimento de limagem e alargamento e na 
telescópica o movimento de limagem. Algumas observações foram feitas:

a) no preparo telescópico as paredes se apresentam mais lisas durante o alargamento;

b) para a remoção de dentina a limagem apresenta-se como menos afetiva;

c)nos canais preparados com a técnica telescópica, as paredes apresentam-se limpas.

Em 1977, HOLLAND et al. ${ }^{32}$ realizaram uma investigação para determinar as características morfológicas do tecido periapical humano, depois da extirpação pulpar e preenchimento imediato do

canal radicular com hidróxido de cálcio. Empregando limas Hedströen, removia-se cuidadosamente a polpa radicular, diminuindo-se $1 \mathrm{~mm}$ da medida do dente na radiografia. Depois de preencher os canais com pasta de hidróxido de cálcio, os dentes eram extraídos em intervalos que variavam de 2 a 180 dias. Após serem fixados, descalcificados e imersos em parafina e seccionados, os dentes foram examinados ao microscópio de luz polarizada. Foi constatado que o processo de cura é similar à quando se usa hidróxido de cálcio na polpa (após pulpotomia, por exemplo), podendo induzir o fechamento apical pela deposição de tecido duro. 
GOLDBERG; ABRAMOVICH ${ }^{24}$, em 1977, empregaram 6 dentes unirradiculados recém-extraídos, com o objetivo de mostrar a ação do EDTAC sobre as paredes dentinárias. Após a instrumentação de seus canais, os dentes foram divididos em duas seções longitudinais, sendo em uma delas colocado EDTAC. Posterior à análise feita em microscópio eletrônico de varredura, observou-se: a) o uso do EDTA ajuda a limpeza e densinfecção das paredes dentinárias, eliminando a camada superficial de resíduos que fica solta quando da instrumentação; b) esta limpeza propicia uma maior adesão entre o material obturador e as paredes dentinárias.

KAUFMAN et al. $^{46}$, no ano de 1978 , realizaram um trabalho tanto in vivo como in vitro, a fim de comparar as propriedades limpadoras do salvisol e do EDTAC. Empregando a microscopia eletrônica de varredura, observaram paredes limpas e secas nos terços cervical e médio, com ausência da smear-layer. No terço

apical, in vivo, os túbulos dentinários estavam vazios, mas podia se observar a presença de detritos. Já no estudo in vitro, no terço apical, também foram observados microrganismos, remanescentes orgânicos e fragmentos de dentina.

Em 1978, Holland et al. ${ }^{33}$ analisaram o efeito do hidróxido de cálcio na dentina, utilizando-se de dois grupos experimentais. No $1^{\circ}$ grupo, tubos de dentina de raízes de dentes humanos, eram preenchidos com cimento de hidróxido de cálcio ou cimento de 
óxido de zinco e eugenol e implantados em tecidos conjuntivo subcutâneo de ratos. No $2^{\circ}$ grupo, foram preparadas cavidades classe $\mathrm{V}$ em dentes de cães, e estas foram protegidas com os mesmos cimentos já citados. Após 48 horas, os espécimes, não descalcificados, foram preparados para exame histológico e analisados com o auxílio de luz polarizada. Apenas na dentina protegida com hidróxido de cálcio, foi observada no interior dos canalículos dentinários, uma estrutura altamente birrefringente àluz polarizada. Este resultado sugere que o efeito do hidróxido de cálcio na dentina é semelhante ao observado quando em contato com a polpa dental. Outra constatação interessante, é que previamente ao emprego do hidróxido de cálcio, seriam benéficos os procedimentos clínicos que desobstruíssem os canalículos dentinários, para não impedir ou mesmo facilitar a penetração do hidróxido de cálcio nos mesmos, aumentando assim a sua eficácia.

Em 1980, BERBERT; BRAMANTE; BERNARDINELLI ${ }^{8}$ recomendaram o emprego do EDTA após preparo químicomecânico, objetivando atuar como dispersante das partículas que cobrem as paredes do canal. Sugeriram a utilização após a instrumentação, bombeando-o no interior do canal por 1 a 2 minutos. Por fim, deve-se fazer uma irrigação final com água destilada ou solução fisiológica.

Para avaliar a eficácia de algumas soluções irrigadoras sobre a parede dentinária, BRANCINI ${ }^{12}$, em 1982, empregou 25 dentes humanos recém-extraídos. Os seguintes líquidos irrigadores foram empregados para limpeza das cavidades: EDTA, 
ácido cítrico a 1\%, tergentol, Dehyquart -A e líquido de Dakin. Após análise ao microscópio eletrônico de varredura, chegou-se æ̀s seguintes conclusões: a) as soluções irrigadoras apresentavam limpeza eficiente, na seguinte ordem crescente: líquido de Dakin, tergentol, Dehyquart-A, ácido cítrico e EDTA; b) estatisticamente, houve diferença significante entre o EDTA, líquido de Dakin e tergentol.

Em 1982, GOLDMAN et al. ${ }^{27}$ utilizaram de microscopia eletrônica de varredura para analisar a limpeza do canal radicular após a instrumentação. Dentes unirradiculados humanos tiveram os seus canais alargados e, então irrigados com REDTA e/ou hipoclorito de sódio a 5,25\%. Após destacar que a smear-layer é originária da instrumentação, os autores constataram sua remoção por agentes quelantes. Também se observou que a combinação dos irrigantes e o próprio hipoclorito de sódio a 5\% apresentam uma boa eficácia na remoção da smear-layer, inclusive dos seus componentes orgânicos.

Em 1983, YAMADA et al. $^{85}$ instrumentaram canais de 40 dentes, usando como líquido irrigador o hipoclorito de sódio a $5,25 \%$. Após a instrumentação final, para analisar a capacidade de limpeza de diferentes soluções quelantes, foram feitas irrigações e a toalete final com as seguintes soluções: soro fisiológico, $\mathrm{NaOcl}$ a 5,25\%, EDTA e ácido cítrico. Após analisar os resultados, chegaram ás seguintes conclusões:

a) o hipoclorito de sódio a 5,25\%, empregado isoladamente produz uma limpeza superficial, sem remover a camada de resíduos dentinários; 
b) a solução salina não é eficaz na limpeza;

c) as soluções quelantes, quando usadas isoladamente, removem a camada de resíduos dentinários, mas os melhores resultados são encontrados quando da combinação de EDTA seguido de hipoclorito de sódio a 5,25\%.

Em 1983, ISHLEY; ELDeeb ${ }^{45}$ analisaram a qualidade do selamento apical de dentes obturados pelas técnicas da condensação lateral com guta-percha e cimento e da termoplastificação da guta-percha com e sem cimento. Foram empregados 60 dentes incisivos e caninos superiores humanos, recentemente extraídos que, após terem as suas coroas eliminadas tiveram seus canais instrumentados e, então, obturados. A termoplastificação da guta-percha foi feita empregando-se o método proposto por Mc Spadden. Após 24 horas as raízes foram imersas em solução de azul de metileno por 48 horas e depois seccionadas longitudinalmente. Depois da análise da penetração do corante, analisou-se estatisticamente os valores observados, o que demonstrou não haver diferença estatística entre a condensação lateral e a termoplastificação, apesar de ter-se uma grande infiltração quando se usa a termoplastificação sem a utilização do cimento.

SANTOS et al. ${ }^{71}$, em 1984, utilizaram 60 dentes humanos extraídos, cujos canais foram irrigados com EDTA, hipoclorito de sódio a $1 \%$ e água bidestilada. O objetivo deste trabalho era analisar a ação do EDTA nas paredes dos canais radiculares quanto à textura, uniformidade e amolecimento dentinário. Os 
dentes foram imersos em azul de metileno, e as infiltrações analisadas ao microscópio ótico. Analisando os resultados, os autores concluíram que a ação do EDTA promove uma liberação da luz dos túbulos dentinários, permitindo uma maior penetração do corante; além do mais, observou-se que as paredes dos canais tratados com aquele agente irrigante apresentavam-se mais uniformes e limpas.

Em 1984, GOLDBERG; MASSONE; SPIELBERG ${ }^{25}$ analisaram o efeito do EDTA e do salvisol na limpeza das paredes dentinárias do canal radicular. Empregaram 12 dentes unirradiculados extraídos, que foram instrumentados e, posteriormente, divididos longitudinalmente em duas secções. Em metade das 24 hemisecções aplicou-se no conduto, por intermédio de conta-gotas, EDTAC e na outra metade salvisol. Analisando-se os resultados ao microscópio eletrônico de varredura constatou-se que, quando do emprego do EDTAC, as superfícies dentinárias apresentavam-se desobstruídas, livres da smear-layer, fato este não constatado quando se empregava 0 salvisol.

Em 1984, MADISON; KRELL ${ }^{53}$, analisando o selamento apical de dentes tratados endodonticamente, avaliaram o efeito do REDTA empregado conjuntamente com o hipoclorito de sódio a $2,5 \%$. Canais de dentes unirradiculados humanos foram

instrumentados e irrigados com NaOCL a 2,5\% ou com REDTA associado ao hipoclorito. Após serem obturados com cones de 
guta-percha e cimento de Grossman pela técnica da condensação lateral, os dentes foram imersos em solução de azul de metileno a $1 \%$. Os resultados foram analisados e concluiu-se que não houve diferenças estatisticamente significantes na penetração do corante, indepedente do líquido irrigador empregado.

Com o objetivo de analisar as características morfológicas da smear-layer em canais que tinham sido instrumentados, MADER; BAUMGARTNER; PETERS ${ }^{52}$, em 1984, após empregarem o microscópio eletrônico de varredura, chegaram as seguintes conclusões:

a) a smear-layer apresenta duas camadas: a camada dentinária da superfície da parede do canal, e o material impactado para dentro dos túbulos dentinários;

b) a smear-layer pode penetrar até 40 micrometros dentro dos túbulos dentinários;

c) a espessura da smear-layer varia entre 1 a 2 micrometros;

d) a adesão da smear-layer æ̀s paredes do canal, parece ser fraca .

Em 1985, ALEXANDER; GORDON ${ }^{3}$ utilizaram sessenta incisivos centrais humanos extraídos, cujos canais foram instrumentados e obturados. O objetivo deste trabalho era comparar o selamento apical produzido, quando do emprego dos cimentos CRCS, Sealapex e tipo Grossman, todos usados na técnica da condensação lateral. Após a qualidade da obturação ser confirmada 
por radiografias proximais e orto-radiais, os dentes foram impermeabilizados, e imersos em corante azul de metileno por seis dias. Removida a impermeabilização, as raízes foram seccionadas horizontalmente em vários níveis, sendo as infiltrações analisadas e estudadas estatísticamente. Os cimentos Sealapex e o tipo Grossman produziram selamentos semelhantes, sendo que ambos apresentaram menos infiltração do que a promovida pelo cimento CRCS.

Empregando a microscopia eletrônica de varredura e observando a penetração bacteriana, foi analisado o selamento apical de obturações dos canais, quando se utiliza o EDTA como agente irrigante. Esta pesquisa, feita por GOLDBERG et al. ${ }^{26} \mathrm{em}$ 1985, onde se empregou 22 dentes unirradiculados humanos extraídos que, tiveram seus canais instrumentados e obturados pela técnica da condensação lateral e cimento Diaket $A$. A seguir, analisaram a qualidade da obturação dos espécimes. Não foi constatada diferença significante estatisticamente entre os grupos, com ou sem o emprego do EDTA.

Em 1986, EVANS; SIMON $^{20}$ realizaram um trabalho científico para analisar o selamento apical proporcionado por obturação com guta-percha termoplastificada, utilizando-se ou não de cimento obturador e com ou sem a presença da smear-layer. Sessenta e quatro dentes humanos unirradiculados tiveram os seus canais instrumentados, mantendo-se o forame sempre patente. Em metade dos dentes removeu-se a smear-layer com o emprego de EDTA, e na outra metade a mesma foi mantida. Nos dois grupos, uma parte foi obturada pela técnica da condensação 
lateral, e outra pela técnica da termoplastificação da guta-percha, associados ou não ao cimento obturador. Quatorze dias após a obturação os dentes foram imersos em tubos com corante da Índia e centrifugados por 20 minutos. Após serem desmineralizados em ácido nítrico a 5\%, desidratados em álcool e clareados em salicilato de metila, os dentes tornaram-se transparentes e as medidas das infiltrações foram feitas e tabuladas. Após análise estatística, observou-se que: o uso do cimento é importante para prevenir a infiltração apical; as duas técnicas de obturação empregadas associadas ao cimento são efetivas quanto ao selamento e que a presença ou ausência da smear-layer não influenciou o selamento apical.

BONETTI FILHO; LEAL; MENDES ${ }^{10}$, em 1987, realizaram um trabalho in vitro para determinar a capacidade seladora de alguns técnicas de obturação. Cento e vinte incisivos centrais superiores humanos extraídos foram instrumentados e obturados empregando-se 6 técnicas diferentes:

a) condensação lateral ativa (biológica controlada);

b) condensação lateral ativa (clássica );

c) condensação lateral passiva;

d) condensação lateral passiva com vibração;

e) técnica de Mc Spadden, em presença de cimento obturador;

f) técnica de Mc Spadden, em ausência de cimento obturador.

Após serem impermeabilizados, os dentes foram imersos em tubos de vidro com o corante Rhodamine B a 0,2\% por 7 dias. Após os dentes terem sido cortados longitudinalmente, as 
infiltrações foram mensuradas e os dados submetidos à análise estatística.

Baseando-se na metodologia deste trabalho, chegou-se as seguintes conclusões:

1) em todos os grupos foram observadas infiltrações;

2) a técnica $\underline{b}$ apresentou a melhor capacidade seladora;

3) a técnica f foi a que apresentou os piores resultados.

Em 1987 HIZAGATU et al. $^{29}$, empregando dentes humanos extraídos, por meio de microscopia eletrônica de varredura, analisaram a qualidade do preparo químico-mecânico dos canais radiculares variando os líquidos irrigadores. Os dentes foram divididos em três grupos:

1) irrigação com líquido de Dakin durante a instrumentação, toalete com EDTA por 15 minutos e irrigação final com soro;

2) emprego do Endo PTC + líquido de Dakin e irrigação final com Tergentol-furacin;

3) irrigação com líquido de Dakin e irrigação final com água destilada. Analisando os resultados, constataram que, no grupo 1 houve a remoção da smear-layer; o grupo 2 apresentava uma boa limpeza dos canais em determinadas áreas; e no grupo 3 as paredes radiculares apresentavam numerosas partículas e irregularidades de superfície. 
Com objetivo analisar a influência de soluções descalcificadoras na qualidade da obturação do sistema de canais radiculares, HOLLAND et al. $^{34}$, em 1988, usaram 80 dentes unirradiculados com presença de canais laterais ou deltas apicais. Divididos em grupos, os espécimes tiveram os canais instrumentados, variando-se o sistema de irrigação:

a) solução de Milton;

b) EDTA a 20\%;

c) solução de Milton e o uso de final de EDTA por 3 minutos;

d) solução de Milton e o uso final de ácido cítrico por 3 minutos.

Após serem obturados pela técnica da condensação lateral, os espécimes foram radiografados e a qualidade das obturações avaliadas. O emprego de soluções descalcificadoras aumentou a quantidade de ramificações preenchidas pelo material obturador, sendo que o emprego do EDTA na toalete final por 3 minutos, foi o procedimento que possibilitou um maior preenchimento das ramificações do canal radicular.

Tendo o propósito de comparar a capacidade de diferentes métodos de irrigação em remover a camada de smear-layer, CIUCCHI; KHETTABI; HOLZ ${ }^{15}$, em 1989, realizaram um estudo in vitro. Foram empregados 40 canais de raízes mesiais de molares humanos extraídos, que foram instrumentados e, posteriormente, divididos em 4 grupos. O grupo 1 serviu como controle. Nos outros, variou-se a irrigação: ultra-som com hipoclorito de sódio, EDTA e EDTA com ultra-som. Os dentes foram selecionados e com o auxílio de microscopia eletrônica de varredura, analisou-se a 
presença da smear-layer nos terços coronário, médio e apical dos canais. Com o emprego do EDTA, ao contrário do hipoclorito de sódio, observou-se a presença de paredes dentinárias livres da smear-layer. O uso do ultra-som, aumentou a eficiência do hipoclorito de sódio. Outra constatação observada, foi que no terço apical dos canais havia um decréscimo na qualidade da irrigação.

KAUFMAN et al. ${ }^{47}$; em 1989, obturaram canais radiculares de dentes humanos extraídos com os cimentos Life e AH 26, empregando o método da termoplastificação com compactadores. O principal objetivo deste trabalho, era avaliar a qualidade do selamento obtido. Depois de obturados, os dentes foram impermeabilizados, imersos em solução de Procion Azul Brilliant por 4 dias e posteriormente desmineralizados em ácido nítrico a $11 \%$ e tornados transparentes em salicilato de metila. Após serem examinados ao estereomicroscópio, as medidas de penetração do corante foram mensuradas e analisadas estatitiscamente. Foi observado que os canais obturados com Life apresentavam uma menor infiltração do que com o AH 26, apesar de que estas medidas não apresentavam significância estatística. Outro detalhe constatado, foi que a guta-percha termoplastificada preenchia a totalidade dos espaços dos canais, inclusive canais acessórios.

Em 1989, BARKHORDAR; BUI; WATANABE instrumentaram e obturaram canais radiculares de 60 dentes humanos extraídos, com o objetivo de comparar a qualidade do 
selamento apical quando se empregava diferentes cimentos obturadores. Os dentes foram divididos em 6 grupos, os quais eram obturados pela técnica da condensação lateral e usando os seguintes cimentos: cimento de Roth, $\mathrm{AH} 26$, Sealapex, CRCS, um cimento sem a presença do eugenol e o grupo controle sem a presença de cimento. Após serem armazenados a $37^{\circ} \mathrm{C}$ por 48 horas, os dentes eram impermeabilizados com duas camadas de esmalte, exceto os $2 \mathrm{~mm}$ apicais, sendo imersos em corante da Índia por 24 horas. Passado este período, removia-se a impermeabilização com acetona, e as raízes eram descalcificadas em ácido fórmico a 20\% por 7 a 10 dias, desidratadas em álcoois (álcool etílico a 85\% por uma noite, 90, 95 e $100 \%$ por uma hora). Depois de serem colocadas em salicilato de metila por 2 ou 3 horas, as raízes apresentavam-se transparentes. Com o auxílio de microscopia, analisava-se a penetração do corante, sendo os resultados estudados estatisticamente. Constatou-se que não havia diferença significante no selamento produzido com uso de todos os cimentos, sendo que na ausência deste a infiltração se mostrou significantemente maior.

Em 1989, SPANGBERG; ACIERNO; $\mathrm{CHA}^{76}$ realizaram um estudo para avaliar o efeito da presença de corantes no interior dos canais radiculares. Criando canais com espaços interiores padronizados, estes autores compararam a penetração do corante azul de metileno a $2 \%$ na ausência e presença de ar. Empregando-se um estereomicroscópio, os resultados foram anotados e analisados estatisticamente. Observou-se que quanto mais estreito o espaço dentro do canal, mais dificuldades serão 
encontradas para a penetração do corante, e que a criação de ambiente com vácuo favorece a penetração do corante no interior do canal.

Em 1989, OLIVEIRA; LIA ${ }^{64}$, com o objetivo de avaliar a limpeza dentinária proporcionada pela água destilada, líquido de Dakin, solução de Milton, soda clorada e água oxigenada, soda clorada e EDTA, instrumentaram canais de pré-molares inferiores humanos. Após análise ao microscópio eletrônico de varredura, os resultados permitiram constatar que: a) o EDTA apresentou maior capacidade de limpeza, mas esta não chegou a apresentar

significância estatística; b) o terço radicular cervical apresentou os melhores índices de limpeza e o apical os piores.

Em 1989, o conceituado "Index Merck ${ }^{58 ", ~ q u e ~ e ́ ~ u m a ~}$ enciclopédia sobre substâncias químicas e drogas, no tópico referente ao azul de metileno, discorre sobre a sua constituição química e propriedades. Um item que podemos destacar é a citação a respeito da incompatibilidade com substâncias fortemente básicas e com agentes redutores.

Em 1990, POLLARD; WELLER; KULID ${ }^{69}$ testaram a influência do tempo decorrido pós-obturação para imersão de dentes na solução marcadora de infiltração. Utilizaram 60 dentes caninos humanos extraídos que após a instrumentação e obturação com cimento e guta-percha, foram divididos em 3 grupos de 20 elementos cada. Imediatamente após a obturação, um grupo era imerso em corante, sendo os outros imersos nos períodos de 1e 7 dias após. Depois de permaneceram por 7 dias 
imersos no corante tinta da Índia, os dentes foram submetidos a tratamento para torná-los transparentes. A avaliação da penetração foi medida com o auxílio de um estereomicroscópio. Após os resultados serem tabulados e analisados estatisticamente, de acordo com as condições experimentais deste trabalho, constatou-se que não havia diferença na infiltração entre os grupos, o que leva a deduzir, que o tempo após a obturação no qual os dentes são imersos em corante, não é crítico.

PORKAEW et al. ${ }^{70}$, em 1990, realizaram um trabalho com o objetivo de analisar a influência da pasta curativa contendo hidróxido de cálcio no selamento apical. Empregando 66 dentes humanos extraídos (caninos e pré-molares) com canais únicos, estes tiveram seus canais instrumentados pela técnica escolonada. Foram divididos aleatoriamente em 4 grupos e preenchidos com $\mathrm{Ca}(\mathrm{OH})_{2}$ USP, Calasept, Vitapex, e o grupo controle sem uso de curativo. Após 1 semana o medicamento era removido com uma lima acima da última empregada e o canal irrigado com solução de hipoclorito de sódio a 5,25\%. Um dente de cada grupo era examinado àmicroscópia eletrônica e os remanescentes obturados com guta-percha, condensação lateral e cimento de Grossman. Após os dentes permanecerem por 2 semanas imersos em corante azul de metileno a $2 \%$, as infiltrações lineares e volumétricas foram observadas. Analisando os resultados, concluiu-se que: 
a) com a aplicação do curativo de hidróxido de cálcio ocorria uma diminuição na infiltração;

b) a utilização de um instrumento mais calibroso do que o último empregado na instrumentação, não é suficiente para remover totalmente o curativo de hidróxido de cálcio;

C) a infiltração nos 3 grupos que receberam o curativo era similar. Para justificar a ação do hidróxido de cálcio, os autores argumentam que a permanência de resíduos de hidróxido de cálcio poderia ter a sua ação explicada por: a) hidróxido de cálcio residual seria incorporado ao cimento obturador, causando por si só, um decréscimo na permeabilidade; b) também pode se admitir que o hidróxido de cálcio, penetrando nos túbulos dentinários, promoveria a sua oclusão, diminuindo a habilidade do corante em penetrar ao redor das paredes do canal; c) pode-se supor que haveria a possibilidade do hidróxido de cálcio reagir para formar carbonato de cálcio, o qual, no entanto, é reabsorvível, o que pode a longo prazo, criar espaços na interface obturação-parede do canal, comprometendo o sucesso do tratamento.

Em 1991, GETTLEMAN; MESSER; ELDeeb ${ }^{23}$ realizaram uma pesquisa com o objetivo de analisar a influência da smearlayer na adesão de cimentos obturadores à dentina. Foram empregados um total de 120 dentes humanos extraídos. Depois de serem seccionados longitudinalmente, uma metade do dente tinha a smear-layer mantida, e na outra metade a smear-layer era removida pela ação do EDTA a $17 \%$ seguido de irrigação com hipoclorito de sódio a 5,25\% fato este averiguado em microscópio eletrônico de varredura. Os dentes foram divididos em grupos e 
preenchidos com os seguintes cimentos obturadores: $\mathrm{AH} 26$, Sultán e Sealapex. Utilizando-se de um dispositivo especial para medir a força de adesão, os resultados foram anotados e analisados estatisticamente. Observou-se que 0 AH 26 apresentava uma adesão mais forte, e o Sealapex uma menor adesão. Já em relação àinfluência da smear-layer na adesão, em relação ao cimento $\mathrm{AH} 26$ foi detectado uma adesão maior na sua ausência.

HOLLAND et al. $^{35}$, em 1991, no intuito de observar a qualidade do selamento marginal de canais radiculares obturados pela técnica da condensação lateral, variaram alguns procedimentos clínicos. Empregando 70 dentes humanos extraídos, estes foram preparados biomecanicamente e, antes da obturação, divididos em 7 grupos experimentais. Em 4 grupos, os canais foram secos respectivamente com cânula aspiradora, cone de papel, cone de papel seco e embebido em álcool e no ambiente por 2 horas. Os outros 3 grupos, após serem secos com cones de papel, receberam curativo de paramonoclorofenol canforado, EDTA e Otosporin, respectivamente. Depois de serem obturados pela técnica da condensação lateral, os dentes foram imersos em solução de azul de metileno a $2 \%$ por 24 horas. Após o dimensionamento das infiltrações e posterior análise estatística, deduziu-se que: a) a qualidade do selamento marginal obtido é muito influenciado pela secagem do canal; b) o emprego do álcool não proporciona melhores resultados; c) o uso do EDTA, como dos curativos de demora, determinou melhora na eficiência do selamento marginal. 
Em 1991, LIMKANGWALMONGKOL et al. ${ }^{50}$, com o objetivo de comparar o nível de penetração apical de corante, quando se empregava diferentes cimentos obturadores, selecionaram 125 dentes unirradiculados humanos extraídos. Após a remoção das coroas, os dentes tiveram os seus canais instrumentados pela técnica step-back, associada a brocas GatesGlidden $n^{\circ} 2$ e 3 . Após cada instrumento, os canais eram irrigados com hipoclorito de sódio a 1\% e EDTA a 15\%. Depois da secagem dos canais, os dentes foram divididos em 5 grupos de 25 elementos cada. Todos os grupos foram obturados empregando-se a técnica da condensação lateral. Ao contrário dos outros grupos, que empregaram os cimentos obturadores, Apexit, Sealapex, Tubli-Seal ou AH 26, no grupo controle não se utilizou cimento obturador. Após serem armazenados em ambiente com $100 \%$ de umidade a $37^{\circ} \mathrm{C}$ por 48 horas, as raízes foram protegidas com esmalte de unha (exceto o ápice) e colocadas em tubos de ensaio com corante azul de metileno a $2 \%$ sendo centrifugados por 3 minutos. Cortes transversais eram feitos de 1 em $1 \mathrm{~mm}$ no terço apical, e as infiltrações mensuradas. Com o estudo estatístico posterior, observou-se que os cimentos obturadores melhoram a qualidade do vedamento quando usados na técnica da condensação lateral, e dentre os cimentos empregados o que apresentou melhores resultados foi o $\mathrm{AH} 26$.

Em 1991, SLEDER; LUDLOW; BOACEK ${ }^{75}$ utilizaram-se de 52 dentes humanos unirradiculados, recém-extraídos, para determinar a infiltração marginal pós-obturação. Como técnica obturadora foi empregada a condensação lateral, e um cimento 
contendo hidróxido de cálcio (Sealapex) e outro àbase de óxido de zinco e eugenol (Tubli-Seal). Após a obturação, os dentes foram imersos em solução salina, que era trocada semanalmente. Passadas 2 ou 32 semanas, os espécimes foram removidos da solução, imersos em corante da Índia por 72 horas e, posteriormente, tornados transparentes. Para determinar a infiltração de cada dente foi empregado um estereomicroscópio, sendo os resultados tabulados e encaminhados à análise estatística. Comparando os dois cimentos, observou-se que a capacidade seladora é semelhante, não apresentando diferenças entre a $2^{\circ}$ e $32^{\circ}$ semanas.

Com o propósito de analisar, comparativamente, a eficiência do selamento marginal obtido após a obturação do canal, pela técnica da condensação lateral, utilizando-se de cones de guta-percha e alguns cimentos obturadores, com ou sem hidróxido de cálcio, HOLLAND et al. ${ }^{36}$, em 1991, trabalharam com 160 dentes humanos unirradiculados. Após serem obturados, os dentes foram divididos em 8 grupos de 20 elementos cada, conforme o cimento empregado na obturação dos canais. Decorridos 24 horas e 75 dias após a obturação os dentes foram imersos por 12 horas em corante de azul de metileno a $2 \%$ sob vácuo proporcionado por uma bomba. Os autores justificam o emprego do vácuo, devido o fato do ar aprisionado no interior dos canais vazios poder impedir a completa penetração do corante. Assim sendo, trabalhos realizados em ambiente sem vácuo, são apenas qualitativos, demonstrando apenas se houve ou não percolação. Dados 
quantitativos, não podem ser extraídos destes trabalhos, em função dos resultados inconstantes e irregulares, determinados pela presença do ar aprisionado. Os dados obtidos foram analisados estatisticamente, e possibilitaram chegar æ̀s seguintes conclusões: a infiltração marginal aos 75 dias é maior que a observada às 24 horas após obturação; a porcentagem de aumento da infiltração marginal, com o passar do tempo variou entre os diferentes cimentos obturadores estudados; os cimentos que promoveram melhor selamento foram os cimentos à base de hidróxido de cálcio e resina epoxi.

KHOURI DIEP ${ }^{48}$, em 1992, utilizou 60 pré-molares inferiores humanos extraídos para avaliar a ação do EDTA, em diferentes formas de apresentação e técnicas de aplicação. Após a instrumentação dos canais pela técnica telescópica, os dentes foram divididos em grupos, de acordo com o tipo de apresentação, técnicas de aplicação de EDTA e a parede a ser avaliada. Após serem seccionados no sentido longitudinal, os espécimes foram preparados para análise ao microscópio eletrônico de varredura, sendo realizadas fotografias que foram ordenadas em ordem decrescente de limpeza. Analisando-se os resultados, deduziu-se que o emprego de produtos à base de EDTA propiciou um aumento na limpeza das paredes do conduto e que nos terços cervicais e

médios das raízes o grau de limpeza é maior do que no terço apical. 
Com o propósito de analisar a influência da remoção do hidróxido de cálcio, usado como curativo entre sessões, no selamento marginal das obturações, em 1993, HOLLAND et al. ${ }^{39}$ realizaram um trabalho em que foram empregados 80 dentes humanos unirradiculados extraídos. Após a eliminação das respectivas coroas e preparo biomecânico até a lima $n^{\circ} 40$ e escalonamento natural e progressivo até a lima $n^{\circ} 80$, os dentes foram divididos em 8 grupos:

I - Após o preparo, os canais foram obturados.

II - Após o preparo, os canais foram preenchidos com EDTA por cinco minutos, depois secos e obturados.

III - Os dentes receberam curativo de hidróxido de cálcio por sete dias. A sua remoção se deu com o auxílio de uma lima de $n^{\circ} 35$ e irrigação com hipoclorito de sódio a 1\%.

IV - O mesmo procedimento do III, porém os canais foram reinstrumentados com limas de $n^{\circ} 35,40,45$.

V - O mesmo procedimento do grupo III porém, ao final, foi empregado o EDTA, da mesma maneira que o grupo II.

VI - Os mesmos procedimentos do grupo IV, mas empregandose o EDTA, da mesma maneira do grupo II.

VII - Controle positivo - canais não obturados.

VIII - Controle negativo - canais obturados e totalmente envolvidos por araldite.

Após a obturação pela técnica da condensação lateral e cimento de óxido de zinco e eugenol, os espécimes foram mergulhados em azul 
de metileno a $2 \%$ por 24 horas. Terminando este prazo, os dentes foram partidos ao meio e com auxílio de ocular micrometrada e lupa estereoscópica as infiltrações marginais foram medidas e os resultados tratados estatisticamente. Os autores chegaram a 3 conclusões:

a) nos canais onde houve emprego prévio do curativo de hidróxido de cálcio, por sete dias, as obturações, exibiram infiltração marginal menor.

b) a utilização de limas endodônticas, de um número maior que o último instrumento que atuou no limite de trabalho para eliminação do hidróxido de cálcio, junto a irrigação com EDTA, não anulou o efeito observado com emprego do curativo.

c) a utilização do EDTA, ao final da instrumentação, também propiciou diminuição da infiltração marginal.

Com o propósito de determinar quantitativamente a difusão de $\mathrm{Ca}^{++}$e $\mathrm{OH}$ através da dentina radicular, na presença ou ausência da smear-layer, FOSTER; KULID; WELLER ${ }^{22}$, em 1993, realizaram um trabalho experimental, em que 40 dentes unirradiculados foram seccionados transversalmente na junção amelocementária e posteriormente instrumentados. Os espécimes foram armazenados em solução salina, sendo o pH e o nível de $\mathrm{Ca}^{++}$medidos depois de 24 horas. Após serem divididos em 4 grupos, as raízes foram irrigadas com solução salina no grupo 1, EDTA a 17 \% seguido de hipoclorito de sódio no grupo 2. No grupo 3 irrigava-se da mesma maneira do grupo 2 , sendo 0 
canal preenchido com pasta de hidróxido de cálcio. No grupo 4 após irrigação final com hipoclorito de sódio, colocou-se hidróxido de cálcio no canal. $\mathrm{O} \mathrm{pH}$ e

o nível de $\mathrm{Ca}^{++}$eram medidos do $1^{\circ}$ ao $7^{\circ}$ dia. Posteriormente, foram criadas pequenas perfurações na raiz e o pH e o nível de $\mathrm{Ca}^{++}$novamente medidos. Após análise dos resultados, observouse que o hidróxido de cálcio difunde do interior do canal radicular para a superfície externa da raiz, sendo que a remoção do smearlayer pode facilitar esta difusão.

Com o objetivo de avaliar o efeito do emprego do hidróxido de cálcio como curativo de demora no selamento marginal após a obturação do canal radicular, em 1993, HOLLAND; MURATA $^{37}$ realizaram uma pesquisa com 100 dentes humanos recém-extraídos. Após os canais terem sido instrumentados, tiveram 60 raízes preenchidas com 3 diferentes pastas àbase de hidróxido de cálcio quimicamente puro:

1 - hidróxido de cálcio com soro fisiológico;

2 - hidróxido de cálcio, óxido de zinco, colofônia e propilenoglicol;

3- hidróxido de cálcio, paramonoclorofenol canforado e glicerina.

Após 7 dias, as pastas foram removidas, os canais obturados pela técnica da condensação lateral, empregando o cimento óxido de zinco e eugenol e sealapex. Após terem suas superfícies externas impermeabilizadas e serem imersos em solução de azul de metileno a $2 \%$ por 12 horas, os dentes foram partidos longitudinalmente e as infiltrações marginais avaliadas e os resultados submetidos à análise estatística. Os mesmos 
permitiram concluir que com o emprego do hidróxido de cálcio como curativo de demora, independentemente do veículo empregado, ocorreu uma diminuição da infiltração marginal nas obturações realizadas com óxido de zinco e eugenol. O mesmo

não foi observado quando o cimento obturador foi o sealapex. Segundo os autores os resultados deixaram bem claro que resíduos de hidróxido de cálcio permaneceram no interior do canal radicular, diminuído a infiltração marginal após a obturação. Para justificar o mecanismo de atuação, os autores entenderam que o contato do cimento obtutador com resíduos de hidróxido de cálcio determinaria não só a aceleração do tempo de presa do cimento, mas principalmente, uma expansão do material obturador, o que possibilitaria melhor selamento marginal.

DALAT; SPANGBERG ${ }^{17}$, em 1994, realizaram um trabalho experimental com o objetivo de comparar a infiltração apical em canais radiculares, onde se empregou o vácuo. Setenta e nove dentes unirradiculados humanos extraídos foram instrumentados, seguindo os princípios propostos pela técnica escalonada. Após serem divididos em 5 grupos de 15 elementos, todos os canais foram obturados com o cimento $\mathrm{AH} 26$ e em cada grupo usou-se uma técnica obturadora diferente: cone único, condensação lateral, condensação vertical, thermafil e ultrafil. Todos os espécimes foram imersos em corante azul de metileno a $2 \%$ e mantidos em vácuo por 30 minutos. Após as raízes serem fraturados longitudinalmente, as medições das infiltrações foram 
feitas usando um estereomicroscópio e uma ocular micrométrica, sendo os resultados analisados estatisticamente, não havendo diferença significante entre os métodos.

AL-GHAMDI; WENBERG ${ }^{4}$, em 1994 fizeram uma revisão dos métodos usualmente empregados para testar a infiltração marginal propiciada por obturações de canais radiculares obturados.

Os principais métodos empregados foram analisados, sendo estes os mais utilizados: penetração do corante, pigmentação pela prata, isótopos radioativos, bactérias e metabólitos bacterianos, técnica eletroquímica, técnica para medir pressão de líquidos. Quanto aos corantes os mais comunente utilizados são o azul de metileno, Rhodamine B, Procion B azul, entre outros.

Em 1995, HOLLAND et al. ${ }^{41}$ pesquisaram a influência do emprego do curativo de hidróxido de cálcio na infiltração de obturações de canais realizadas pela técnica da condensação lateral. Cento e quarenta dentes humanos unirradiculados extraídos foram instrumentados até a lima tipo $\mathrm{K} \mathrm{n}^{\circ} 40$, sendo que na seqüência foram empregados os princípios da técnica telescópica. Os espécimes foram divididos em 3 grupos:

a) 60 dentes que receberam curativo com hidróxido de cálcio associado ao propilenoglicol;

b) 60 dentes que não receberam curativos;

C) 20 dentes que funcionaram com o controle. Sessenta dentes do grupo A, após a remocão do hidróxido de cálcio, foram subdivididos em 6 grupos de 10 elementos cada. 
Seus canais radiculares foram progressivamente alargados com limas, sendo empregada a de $n^{\circ} 40$ no $1^{\circ}$ grupo, até a de $n^{\circ} 45$ no $2^{\circ}$ grupo, 50 no $3^{\circ}$ grupo, 55 no $4^{\circ}$ grupo, 60 no $5^{\circ}$ grupo e a 70 no $6^{\circ}$ grupo. Os outros 60 dentes foram instrumentados da mesma maneira. Todos os 120 dentes foram obturados pela técnica da condensação lateral com cones de guta-percha e cimento de óxido de zinco e eugenol. Depois de ficarem 24 horas em água, os

espécimes foram imersos em solução de azul de metileno por 24 horas. $\quad \mathrm{Na}$ seqüência, os dentes foram fraturados longitudinalmente e as infiltrações mensuradas com o emprego de um estereomicroscópio e ocular micrometrada. Após análise estatística dos resultados, foi constatado que nos dentes que receberam curativo com hidróxido de cálcio houve menor infiltração, fato este que levou os autores a suporem que o hidróxido de cálcio possa ter alguma atuação na dentina.

Em 1995, ALHBERG; ASSAVANOP; TAY ${ }^{1}$ compararam a capacidade de penetração do azul de metileno a 5\% e do corante da Índia em obturações de canais radiculares. Utilizaram 120 canais de dentes humanos extraídos, cujos canais foram instrumentados pela técnica escolonada e após serem divididos aleatoriamente em grupos, foram obturados pela técnica de condensação lateral com os seguintes cimentos: Tubli-seal, Sealapex e Ketac-Endo. Também foram usados dois grupos para controle, o positivo que foi obturado sem cimento, e o negativo, que apresentava os ápices dos dentes selados. Todos os dentes 
foram impermeabilizados com esmalte de unha e imersos no corante azul de metileno a 5\% ou no corante da Índia por sete dias. Após este prazo, removia-se a impermabilização, sendo as raízes fraturadas longitudinalmente. Com 0 auxílio de um estereomicroscópio, as infiltrações eram analisadas e os resultados levados ao estudo estatístico. Em todos os grupos, o azul de metileno demonstrou estatisticamente uma penetração maior do que o corante da Índia. Segundo os autores, o fato do azul de metileno apresentar um peso molecular mais baixo, poderia facilitar a difusão, penetrando nos túbulos dentinários, inclusive em canais acessórios.

Em 1995, SEN; WESSELINK; TÜRKÜN ${ }^{72}$, fizeram uma revisão da literatura a respeito da smear-layer. Ao microscópio eletrônico de varredura, é descrita como uma camada amorfa, irregular e de aparência granular, sendo constituída de dentina, remanescentes de tecido pulpar, processos odontoblásicos, podendo, inclusive, apresentar bactérias. Os autores que são favoráveis à sua remoção, justificam-na afirmando que a smearlayer apresenta-se como uma camada permeável às bactérias podendo, inclusive, dificultar a ação dos medicamentos empregados como curativo. Além disto, pode atuar como uma barreira física que irá dificultar a adesão e penetração dos cimentos obturadores nos túbulos dentinários, comprometendo a eficiência da obturação. O EDTA e o hipoclorito de sódio se mostram eficazes para a sua remoção. Apresentando opiniões opostas, também são citados alguns autores que enfatizam a importância da permanência da smear-layer, pois ela poderia atuar 
como uma barreira física contra as bactérias e seus produtos. Além disso, são citados alguns trabalhos que afirmam que a qualidade da obturação independe da remoção ou não da smearlayer.

Em 1995, HOLLAND; MURATA; SALIBA ${ }^{40}$ desenvolveram um trabalho para verificar a interferência do curativo de demora com hidróxido de cálcio na qualidade seladora da obturação de canal, a curto e médio prazos. Cento e quarenta dentes humanos unirradiculados extraídos foram instrumentados sob abundante irrigação com hipoclorito de sódio a 1\%. Após serem impermeabilizados com araldite, exceção feita ao forame apical, os dentes foram divididos em grupos. Sessenta dentes receberam um curativo de hidróxido de cálcio com água destilada por sete dias; outros sessenta não receberam curativo e 20 serviram com controle. Decorridos 7 dias, o hidróxido de cálcio foi removido com o auxílio de limas e irrigação. Posteriormente, todos os 120 dentes foram obturados pela técnica da condensação lateral com cones de guta-percha e os seguintes cimentos obturadores: Fill canal, AH 26 e Apexit. Vinte e quatro horas após a obturação, metade dos espécimes tratados e do grupo controle foram imersos em solução traçadora azul de metileno a $2 \%$ sob vácuo. Os demais dentes foram totalmente imersos em água e assim mantidos a 37\% durante 30 dias, após 0 que também foram imersos na solução traçadora. Todos os dentes permaneceram imersos em corante por 12 horas. Após este período os espécimes foram partidos longitudinalmente e as aréas de infiltração dimensionadas com o auxílio de uma lupa 
estereoscópica e uma ocular micrometrada. Analisando-se os resultados e submetendo-os ao estudo estatístico os autores chegaram æ̀s seguintes conclusões:

a) a infiltração marginal observada aos 30 dias, após a obturação dos canais radiculares, foi maior do que a assinalada quando decorridos apenas 24 horas;

b) o curativo de demora com hidróxido de cálcio determinou melhor vedamento do canal radicular;

c) o efeito da utilização do hidróxido de cálcio como curativo de demora persiste por 30 dias;

d) d) as infiltrações observadas nos cimentos empregados foram diferentes entre si.

WAKABAYASHI et al. ${ }^{81}$, em 1995, realizaram um trabalho experimental para avaliar o efeito da pasta de hidróxido de cálcio na

pré-dentina e na camada odontoblástica da parede de canais radiculares, depois da remoção do tecido pulpar. Após dividir ao meio raízes de dentes unirradiculados humanos, promovia-se a remoção do tecido pulpar. Depois de serem divididos em grupos, os dentes foram estocados em pasta de hidróxido de cálcio, em períodos que variavam de 7 a 28 dias. Utilizando-se da microscópia eletrônica de varredura, as paredes dos canais radiculares foram analisadas. O desaparecimento total da camada odontoblástica pode ser observado. Já a pré-dentina, apenas no grupo que empregou a pasta de hidróxido de cálcio por mais tempo, é que apresentou uma pequena erosão. Este 
desaparecimento do processo odontoblástico sugere que ions hydroxila poderiam penetrar até a pré-dentina, podendo exercer um efeito antimicrobiano. Assim sendo, seria importante a repetição de curativo com pasta de hidróxido de cálcio para desinfeção e limpeza de um canal radicular infectado.

Em 1996, HOLLAND et al. ${ }^{43}$ analisaram o selamento marginal obtido após a obturação de canais com quatro diferentes cimentos obturadores àbase de hidróxido de cálcio. Utilizando 50 dentes humanos unirradiculados extraídos, os canais foram instrumentados, impermeabilizados com araldite e obturados pela técnica da condensação lateral, empregando os seguintes cimentos: Sealapex, Apexit, CRCS, e Sealer 26 e, com controle 0 óxido de zinco e eugenol. Após a impermeabilização da sua superfície externa, os dentes foram obturados e então mergulhados em água por 24 horas e, posteriormente, imersos em solução de azul de metileno a $2 \%$ em ambiente com vácuo. Após 12 horas, os espécimes foram lavados, secos e cortados ao meio no sentido longitudinal. Com o auxílio de uma lupa estereoscópica e uma ocular micrometrada, procedeu-se às medidas das infiltrações marginais. Posterior à análise estatística, constatou-se que os cimentos à base de hidróxido de cálcio exibem melhor vedamento do que o cimento de óxido de zinco e eugenol; os cimentos Sealapex, Apexit, exibiram resultados semelhantes entre si e apresentam menor percolação do que o CRCS.

Em 1996, HOLLAND et al. ${ }^{42}$ realizaram um trabalho para analisar in vitro o selamento apical de canais radiculares obturados 
com cones de guta-percha com hidróxido de cálcio na ponta. Foram empregados 110 dentes humanos unirradiculados extraídos. Após serem instrumentados até a lima tipo $\mathrm{K} \mathrm{n}^{\circ} 40$, os dentes foram divididos em grupos. Alguns receberam curativo de hidróxido de cálcio associado ao propilenoglicol. Todos os dentes foram obturados pela técnica da condensação lateral com o uso de guta-percha com ou sem hidróxido de cálcio na sua porção apical. Após serem imersas em corante azul de metileno a $2 \%$ e submetidas ao vácuo, as raízes foram partidas no sentido bucolingual e os resultados medidos com uso do estereomicroscópio e ocular micrométrica. A análise dos resultados demonstrou que o emprego do curativo de hidróxido de cálcio e também da gutapercha com hidróxido de cálcio na ponta melhoram a qualidade do selamento apical da obturação. Quanto ao questionamento a respeito da possibilidade de que com o passar do tempo, 0 hidróxido de cálcio da superfície da ponta da guta-percha poderia reagir com o $\mathrm{Co} 2$ e formar o $\mathrm{CaCO}_{3}$ (que não apresenta o mesmo efeito do hidróxido de cálcio), os autores argumentam que quando da condensação lateral, o espaçador poderá pressionar a gutapercha e liberar algum hidróxido de cálcio que está localizado na ponta do cone, podendo ocorrer um melhor selamento apical, pela produção de uma expansão volumétrica do cimento.

Em 1996, MALTOS et al. $^{54}$, preocupados com a qualidade do selamento apical das obturações do canais radiculares, realizaram um trabalho como objetivo de avaliá-lo. Utilizaram-se de análise radiográfica e marcação de infiltração por meio de corante. Foram empregados 48 molares humanos 
extraídos, com curvaturas classificadas como classe II. Após serem feitas radiografias padronizadas, os dentes foram instrumentados empregando limas tipo K, brocas de Gates Glidden, hipoclorito de sódio e EDTA. Após serem divididos em grupos, parte dos espécimes foram obturados empregando a técnica de condensação lateral, cones ML, M, FM e cimento obturador (grupo I), e outra parte obturada pela mesma técnica, sendo que os cones usados foram os estandardizados (grupo II). Após a embocadura dos canais e parte coronária serem vedadas com pasta zinco-enólica e cimento de óxido de zinco eugenol, os espécimes foram impermeabilizados, exceto a região do forame apical e coronária. Posteriormente, foram imersos em solução de azul de metileno a $2 \%$ por 7 dias. Depois de removida a impermeabilização os espécimes foram clivados longitudinalmente. Avaliou-se radiograficamente a qualidade das obturações quanto à adaptação, preenchimento do canal e selamento apical. Empregando-se uma lupa esterioscópica analisou-se a intensidade da penetração do corante. Quanto à análise radiográfica todos os espécimes do grupo I e a maioria dos grupo II apresentaram resultados satisfatórios quanto à qualidade da obturação. Já no item relacionado à infiltração, observou-se que os espécimes do grupo I apresentavam uma maior intensidade do que os do grupo II. Os autores contataram que em todos os casos foi observado a infiltração do corante, sugerindo que o selamento apical obtido não atuou como uma barreira impermeável. Outra conclusão, é que a análise 
radiográfica não é método eficiente para qualificar o selamento apical.

Em 1997, KONTAKIOTIS; WU; WESSELINK ${ }^{49}$ questionaram o efeito do curativo de hidróxido de cálcio como fator importante para melhorar a qualidade do selamemto apical das obturações de canais radiculares. Os autores argumentaram que a azul de metileno é amplamente usado em pesquisas como marcador de infiltrações mas pouco se conhece sobre reações entre este material e vários outros testados. Outra constatação feita, é que há uma variação muito grande nos resultados encontrados, apesar dos métodos experimentais empregados serem semelhantes. Neste trabalho, foram empregados oitenta incisivos centrais humanos extraídos que após terem as suas coroas removidas, foram alargados com brocas de Gates-Glidden e brocas do sistema Para Post, tendo como objetivo a padronização do diâmetro. Os espécimes foram divididos em 2 grupos de 40 elementos cada. As raízes do grupo 1 recebiam curativo de hidróxido de cálcio e soro fisiológico, levado ao canal com espiral Lentullo. Já as raízes do grupo 2 não eram preenchidas com curativo. As embocaduras dos canais foram seladas com cavit e os espécimes armazenados a $37^{\circ} \mathrm{C}$ e $100 \%$ de umidade por 15 dias. Após este período, o curativo era removido com a mesma broca do sistema Para Post usada anteriormente, irrigação com água destilada e os canais secos com cones de papel. Os canais dos 80 dentes foram então, obturados pela técnicas da condensação lateral, utilizando 0 cimento Tubli-seal e cones de guta-percha. Foram determinados 
dois sistemas para mensurar a infiltração. O primeiro, empregava um dispositivo que media o transporte de fluido. Este consistia de um tubo capilar de vidro estandardizado conectado a um tubo de plástico ao redor do espécime. Mantido em um recipiente com água, usava-se uma seringa para sugar a água até $3 \mathrm{~mm}$ da abertura final do tubo de vidro, criando uma bolha de ar dentro. Empregando-se uma pressão de 60 KPA no lado coronário forçava a água ir ao encontro dos vazios da obturação, promovendo então, um deslocamento das bolhas de ar no tubo capilar. O volume de transporte do fluido era mensurado pela observação do movimento de bolha de ar, assim sendo, o deslocamento era registrado como semelhante ao do transporte do fluido. Os espécimes foram avaliados em intervalos de 48 horas, 2, 4, 8 e 16 semanas após a obturação. O segundo método de análise da infiltração foi observado após imersão dos espécimes em soluções de azul de metileno a $1 \%$ por 48 horas. Após este período, dividia-se as raízes longitudinalmente e a penetração do corante era avaliada microscopicamente. Os resultados demonstraram que havia uma diferença estatisticamente significante nos grupos experimentais apenas quando se empregava o método que media a infiltração do corante, fato este não constatado no modelo experimental de transporte do fluido. Os autores argumentaram que os baixos valores de infiltração do azul de metileno quando se emprega um curativo prévio de hidróxido de cálcio podem ser explicados pela incompatibilidade do azul de metileno com substâncias alcalinas, sendo aquele "descolorido" pelo 
hidróxido de cálcio. Outra observação importante, é que a penetração do corante também pode sofrer interferência de outros fatores, como por exemplo a presença de ar no interior das obturações.

Em 1997, MARGELOS et al. ${ }^{55}$ realizaram uma pesquisa para avaliar se ocorria alguma interação entre os resíduos de hidróxido de cálcio utilizado como curativo entre sessões e cimentos de óxido de zinco e eugenol. Também foi avaliada a eficiência de vários agentes na remoção deste curativo. Inicialmente espatulava-se o cimento: óxido de zinco e eugenol, Roth 811 e Procosol, seguindo-se as orientações do fabricamte. Pequenas camadas de pasta de hidróxido de cálcio eram incorporadas aos cimentos. Por meio de um espectroscópico analisou-se o efeito do hidróxido de cálcio no mecanismo de endurecimento dos cimentos. Em outra etapa deste trabalho, foram instrumentados 20 dentes que tiveram seus canais secos e totalmente preenchidos com pasta de hidróxido de cálcio. Após o selamento com bolinhas de algodão e Cavit, estocavam-se os dentes por três dias em $100 \%$ de umidade relativa. Decorrido esse prazo, vários agentes eram empregados para avaliar a eficiência da remoção deste curativo. Analisando os resultados, observa-se que existe uma interação entre o hidróxido de cálcio e o eugenol, sendo que os cimentos apresentam-se quebradiços e granular em sua estrutura. A intensidade da atuação do hidróxido de cálcio é proporcional a superfície na qual ele está em contato. Assim sendo, quanto menos eficaz a sua remoção, maior será a interferência no mecanismo de endurecimento do cimento, 
podendo criar desde uma dificuldade para a introdução do cone de guta-

percha em toda extensão de trabalho, até mesmo comprometer a capacidade seladora do cimento, que poderá levar ao insucesso da obturação com o decorrer do tempo. Dos mecanismos empregados para a remoção do hidróxido de cálcio, o que se mostrou mais eficaz foi a instrumentação associada com a irrigação com o hipoclorito de sódio e EDTA.

Em 1997, CALERO et al. ${ }^{14}$ verificaram através do método de espectofotometria de absorção atômica, a velocidade e intensidade na qual o EDTA reage com os íons cálcio da dentina e o nível da saturação, de acordo com a sua permanência. Foram empregados 256 dentes humanos, que tiveram os seus canais instrumentados e posteriormente preenchidos com EDTA. Após serem divididos em grupos, os dentes tiveram o EDTA removido, depois de respeitados os tempos experimentais determinados, sendo a solução enviada ao exame laboratorial. Observou-se que a descalcificação produzida pelo EDTA na dentina é progressiva e que, a partir de um determinado momento, a sua intensidade vai diminuindo. Assim sendo, clinicamente é recomendado aguardar 1 minuto após a aplicação do EDTA e que no final seja feita uma rigorosa irrigação com soro fisiológico para a sua completa remoção.

Em 1998, WU; KONTAKIOTIS; WESSELINK ${ }^{84}$ constataram que um grande número de trabalhos sobre infiltrações em obturações de canais radiculares, enfatizam o selamento hermético proporcionado pelo material obturador como 
clinicamente importante. A grande maioria destes experimentos empregam o azul de metileno como solução marcadora de infiltração. Com o objetivo de analisar a estabilidade da cor do azul de metileno em contato

com alguns materiais obturadores foi realizada esta pesquisa. Foram utilizados setenta tubos de plástico de diâmetros e tamanho padronizados, bem como setenta incisivos centrais superiores extraídos, que tiveram as coroas e $3 \mathrm{~mm}$ apicais da raiz cortados. Após o diâmetro dos canais terem sido padronizados, com brocas Gates-Glidden, as raízes foram estocadas em água destilada. Dez raízes e dez tubos de plásticos foram obturados com os seguintes materiais: amálgama, pasta de hidróxido de cálcio e soro fisiológico, cimento de óxido de zinco e eugenol (OZE), ionômero de vidro (Fuji II) cavit, um cimento temporário contendo óxido de zinco, eugenol e sulfato de cálcio e o cimento trioxide agregado mineral (MTA). Armazenados em pequenos recipientes de plástico, os espécimes foram imersos em solução de azul de metileno a 1\%. Empregando um espectrofotômetro, a densidade ótica do azul de metileno foi mensurada antes da imersão e 24, 48 e 72 horas após. As variações nos valores da densidade ótica foram registradas para cada intervalo de tempo e analisadas estatisticamente. A solução de azul de metileno sofria a descoloração durante os intervalos testados, para todos os materiais, exceção feita ao material Fuji II. Em relação ao hidróxido de cálcio, o valor da densidade ótica diminuia significantemente, fato este também observado com MTA. Os autores destacam que o azul de metileno é instável em contato 
com substâncias alcalinas, podendo descolorir-se. Este é o caso do hidróxido de cálcio, e também do óxido de cálcio contido no MTA que em contato com água irá formar hiróxido de cálcio. Os outros materiais citados no trabalho, sofreram uma descoloração provavelmente devido a imcompatibilidade do azul de metileno com agentes redutores, como o zinco, cobre e prata. Assim sendo, os autores alertam que vários trabalhos que mensuravam a penetração do azul de metileno nos espaços vazios da obturação, podem ter tido os seus resultados analisados de maneira incorreta. Também sugerem o emprego de outras substâncias marcadoras e a necessidade da análise da densidade ótica ser feita antes do experimento. 
3 - PROPOSIÇÃO 


\section{3 - PROPOSIÇÃO}

Diante das dúvidas aventadas na introdução e constatadas na revisão de literatura, realizou-se este trabalho com os seguintes propósitos:

$\Rightarrow$ avaliar a influência do hidróxido de cálcio na magnitude da infiltração marginal de corante azul de metileno a $2 \%$ propiciada por obturações de canais radiculares realizadas pela técnica da condensação lateral, utilizando-se cimento obturador ou pasta de hidróxido de cálcio.

$\Rightarrow$ avaliar, indiretamente por meio da análise da infiltração marginal, o efeito do EDTA, no selamento apical, aplicado prévia e/ou posteriormente à utilização do curativo com hidróxido de cálcio ou anteriormente àobturação. 


\section{4 - MATERIAL E MÉTODOS}




\section{4 - MATERIAL E MÉTODOS}

\section{1 - Seleção e preparo dos dentes}

Foram selecionados 188 dentes incisivos superiores humanos extraídos com raízes completamente formadas e canais únicos. Após a extração, devido a várias causas, os dentes foram imersos em solução de formaldeído a $10 \%$ por 30 dias. A eliminação do tecido mole que estava aderido à raiz foi feita por raspagem com instrumentos adequados. Os dentes ficaram, então, armazenados em água destilada. Foram tomadas radiografias orto-radiais e/ou, quando necessário, disto ou mésioradiais para se confirmar o número de canais existentes. Com o intuito de facilitar a instrumentação dos canais radiculares, as coroas dos dentes foram previamentes eliminadas, utilizando-se broca carbide $n^{\circ} 1557$. Somente foram empregadas as raízes que apresentavam comprimento entre 11 e $13 \mathrm{~mm}$. A instrumentação dos canais foi realizada com lima tipo Kerr de $21 \mathrm{~mm}$, utilizando-se a técnica de instrumentação escalonada regressiva. A determinação do comprimento de trabalho foi estabelecida utilizando-se de lima tipo $\mathrm{K} \mathrm{n}^{\circ} 08$ munida de limitador de penetração de borracha. A mesma era introduzida no canal até que sua guia de penetração fosse visualizada na altura do forame apical. O limitador era, então, posicionado tocando a borda cervical da raiz em questão e a lima retirada do canal. A distância entre a ponta do instrumento e o limitador de penetração era anotada, sendo esta considerada a extensão de trabalho até a lima 
de $n^{\circ}$ 30. Após a utilização de cada instrumento o canal era irrigado, utilizando-se uma seringa Luer-

Look com capacidade de $5 \mathrm{ml}$, tendo o bico de metal e cânula $\mathrm{n}^{\circ}$ 4. O hipoclorito de sódio a 1\%, foi o líquido irrigador empregado. Procurou-se preparar no máximo 15 dentes por dia de trabalho.

\section{2 - Técnica de instrumentação}

A instrumentação era iniciada com uma lima tipo $k n^{\circ} 10$ no comprimento total do canal, sendo empregados movimentos de 1/4 de volta no sentido horário e remoção da lima de 1,0 a 2,0 mm forçando-a contra uma das paredes, até que todas as paredes tivessem sido instrumentadas. Cada lima só era removida do canal, quando estivesse totalmente folgada. Logo em seguida, fazia-se irrigação com $1 \mathrm{ml}$ de hipoclorito de sódio a 1\%. Dando seqüência à técnica, instrumentou-se com limas tipo $K$ de diâmetros progressivamente maiores. A mesma seqüência técnica citada anteriormente era realizada, sendo que a instrumentação estendia-se até a lima $n^{\circ} 30$. Raízes, cujos canais apresentavam-se com forames apicais com diâmetros superiores a essa medida foram descartadas e substituídas por outras. Diminuindo-se $1 \mathrm{~mm}$ no comprimento de trabalho até então utilizado, passou-se à determinação do degrau apical de instrumentação, usando seqüencialmente as limas n³5, 40 e 45. Nestas limas empregava-se os mesmos princípios técnicos anteriores, sendo que a lima só era trocada quando estivesse folgada no interior do canal. Após cada lima, irrigava-se o canal 
com $1 \mathrm{ml}$ de hipoclorito de sódio a 1\%. A lima $\mathrm{K}$ de $\mathrm{n}^{\circ} 45$ foi considerada como de memória, penetrando em toda a extensão de trabalho (extensão total - $1 \mathrm{~mm}$ ). Na seqüência,

foi estabelecido o escalonamento regressivo, utilizando 03 instrumentos de diâmetros progressivamente maiores do que a lima memória, ou seja, limas $n^{\circ} 50,55$ e 60. A cada aumento no calibre dos instrumentos diminuía-se $1 \mathrm{~mm}$ da extensão de trabalho. Assim sendo, a lima $n^{\circ} 50$ tinha um comprimento de trabalho de $1 \mathrm{~mm}$ a menos do que a $\mathrm{n}^{\circ} 45$; a $\mathrm{n}^{\circ} 55$ tinha $2 \mathrm{~mm}$ a menos do que a $n^{\circ} 45$ e a $n^{\circ} 60$ tinha $3 \mathrm{~mm}$ a menos do que a $\mathrm{n}^{\circ}$ 45. A troca da lima ocorria quando ela estava folgada no interior do canal. Após irrigação do mesmo, com hipoclorito de sódio, reintroduzia-se o instrumento de memória (lima tipo $\mathrm{K} \mathrm{n}^{\circ} 45$ ), antes de passar para a lima seguinte. Visando aproximar-se das condições clínicas, a partir do instante em que a instrumentação passou a ser realizada com a lima $n^{\circ} 35$, o forame apical foi obstruído com cera utilidade. Assim, todo o líquido injetado no canal, obrigatoriamente, seria refluído via cervical. Para finalizar a instrumentação foram utilizadas brocas Gates-Glidden. Optou-se pelo emprego das brocas de $n^{\circ} \mathrm{s} 3,4$ e 5 . Nas brocas eram colocadas limitadores de penetração. A extensão de trabalho das mesmas foi baseada na medida empregada para a lima 60, de tal maneira que a broca $\mathrm{n}^{\circ} 3$ penetrava $1 \mathrm{~mm}$ a menos que a lima 60 , a $\mathrm{n}^{\circ} 4$ a $2 \mathrm{~mm}$ e a $\mathrm{n}^{\circ} 5$ a $3 \mathrm{~mm}$. O acionamento era feito em baixa rotação, evitando fazer pressão apical. Após o uso de cada broca, 
irrigava-se o canal com $1 \mathrm{ml}$ de hipoclorito de sódio a 1\%. Com o objetivo de remover raspas de dentina, no final reutilizava-se a lima de $\mathrm{n}^{\circ} 30$ no comprimento total de trabalho. 


\section{3 - Impermeabilização dos dentes}

Para a impermeabilização de toda a superfície externa da raiz, deixando exposto apenas o forame apical, foi empregada a seqüência descrita à seguir. $\mathrm{Na}$ parte cervical do canal foi introduzido um palito roliço de madeira (palito de dente), com o objetivo de facilitar o manuseio da raiz. Com um pincel aplicou-se uma fina camada de araldite de presa rápida (CIBA-Geigy S/A Brasil), deixando tomar presa por um dia. Neste intervalo o palito com a raiz era fixado em uma espuma. Passadas 24 horas, foi aplicada uma nova camada de araldite. Após outras 24 horas foi aplicada uma camada de esmalte para unhas, em toda a superfície da raiz, completando a impermeabilização. Os palitos foram fixados na espuma da mesma maneira já citada. Como precaução, para evitar a obstrução do forame, pelos agentes impermeabilizadores, durante a aplicação colocou-se uma lima tipo $\mathrm{K} \mathrm{n}^{\circ} 10$ obstruindo o forame. Um total de 180 raízes foi, inicialmente dividido em 3 grupos de 60 elementos cada, de acordo com os procedimentos operatórios que seriam futuramente realizados. Na seqüência, cada grupo foi dividido em dois subgrupos, os quais, por sua vez, foram subdivididos em dois, totalizando assim 12 subgrupos com 15 elementos, dessa forma descritos:

\section{$\Rightarrow$ GRUPO I (60 elementos)}

Obturação imediata (sem curativo com pasta de hidróxido de cálcio). 


\section{Subgrupo I - 1 - (30 elementos)}

Aplicação de EDTA por 3 minutos antes da obturação.

\section{Subgrupo I-1.1 (15 elementos)}

Obturação com cimento de óxido e eugenol (condensação lateral).

\section{Subgrupo I-1.2 - (15 elementos)}

Obturação com pasta de hidróxido de cálcio (condensação lateral).

Subgrupo I -2- (30 elementos)

Obturação sem a aplicação prévia de EDTA.

\section{Subgrupo I - 2.1 - (15 elementos)}

Obturação com cimento de óxido de zinco e eugenol (condensação lateral).

\section{Subgrupo I-2.2- (15 elementos)}

Obturação com pasta de hidróxido de cálcio (condensação lateral).

\section{$\Rightarrow$ GRUPO II (60 elementos)}

Após a instrumentação, aplicação de EDTA por 3 minutos em todos os canais e preenchimento dos mesmos com pasta de hidróxido de cálcio (curativo).

\section{Subgrupo II-1 - (30 elementos)}

Remoção da pasta de hidróxido de cálcio e aplicação de EDTA.

\section{Subgrupo II-1.1 - (15 elementos)}

Obturação dos canais com cimento de óxido de zinco e eugenol (condensação lateral).

\section{Subgrupo II-1.2- (15 elementos)}


Obturação dos canais com pasta de hidróxido de cálcio (condensação lateral).

\section{Subgrupo II -2- (30 elementos)}

Remoção da pasta de hidróxido de cálcio (curativo), sem nova aplicação de EDTA.

\section{Subgrupo II-2.1 - (15 elementos)}

Obturação dos canais com cimento de óxido de zinco e eugenol (condensação lateral).

\section{Subgrupo II-2.2- (15 elementos)}

Obturação dos canais com pasta de hidróxido de cálcio (condensação lateral).

\section{$\Rightarrow$ GRUPO III (60 elementos)}

Após a instrumentação, preenchimento dos canais com pasta de hidróxido de cálcio (curativo) sem o emprego prévio do EDTA.

\section{Subgrupo III-1- (30 elementos)}

Remoção da pasta de hidróxido de cálcio (curativo) e aplicação de EDTA por 3 minutos.

\section{Subgrupo III-1.1 - (15 elementos)}

Obturação com cimento de óxido de zinco e eugenol (condensação lateral).

\section{Subgrupo III-1.2- (15 elementos)}

Obturação com pasta de hidróxido de cálcio (condensação lateral). 
Remoção da pasta de hidróxido de cálcio (curativo) e não aplicação de EDTA antes da obturação.

\section{Subgrupo III-2.1 - (15 elementos)}

Obturação com cimento de óxido de zinco e eugenol (condensação lateral).

\section{Subgrupo III-2.2- (15 elementos)}

Obturação com pasta de hidróxido de cálcio (condensação lateral).

Também foram usados 8 dentes como controle. Após a instrumentação dos canais, os espécimes foram divididos em dois grupos. Quatro dentes tiveram as suas raízes totalmente impermeabilizadas, atuando como controle negativo. Os outros 4 dentes foram impermeabilizados externamente, deixando apenas 0 forame apical exposto. Após serem imersos em azul de metileno por 72 horas, os espécimes foram seccionados longitudinalmente.

Quadro esquemático com os subgrupos e a metodologia empregada em cada um

\begin{tabular}{|c|l|c|c|c|c|c|}
\hline Grupo & Subgrupo & EDTA & Curativo & EDTA & OZE & $\begin{array}{c}\text { Pasta de Hidróxido } \\
\text { de Cálcio }\end{array}$ \\
\hline \multirow{4}{*}{ I } & $\mathrm{I}-1.1$ & $\mathrm{X}$ & & & $\mathrm{X}$ & \\
\cline { 2 - 7 } & $\mathrm{I}-1.2$ & $\mathrm{X}$ & & & & $\mathrm{X}$ \\
\cline { 2 - 7 } & $\mathrm{I}-2.1$ & & & & $\mathrm{X}$ & \\
\cline { 2 - 7 } & $\mathrm{I}-2.2$ & & & & & $\mathrm{X}$ \\
\hline \multirow{4}{*}{ II } & $\mathrm{II}-1.1$ & $\mathrm{X}$ & $\mathrm{X}$ & $\mathrm{X}$ & $\mathrm{X}$ & \\
\cline { 2 - 7 } & $\mathrm{II}-1.2$ & $\mathrm{X}$ & $\mathrm{X}$ & $\mathrm{X}$ & & $\mathrm{X}$ \\
\hline \multirow{7}{*}{} & $\mathrm{II}-2.1$ & $\mathrm{X}$ & $\mathrm{X}$ & & $\mathrm{X}$ & \\
\hline
\end{tabular}




\begin{tabular}{|c|l|c|c|c|c|c|}
\cline { 2 - 7 } & II-2.2 & $X$ & $X$ & & & $X$ \\
\hline \multirow{4}{*}{ III } & $I I I-1.1$ & & $X$ & $X$ & $X$ & \\
\cline { 2 - 7 } & $I I I-1.2$ & & $X$ & $X$ & & $X$ \\
\cline { 2 - 7 } & $I I I-2.1$ & & $X$ & & $X$ & \\
\hline & $I I I-2.2$ & & $X$ & & & $X$ \\
\hline
\end{tabular}




\section{4 - Procedimentos em comum}

Alguns procedimentos foram empregados de maneira similar em vários grupos. Evitando-se a repetição, será feita uma descrição geral.

\subsection{1 - Irrigação}

Durante a instrumentação, para todos os grupos, os canais foram irrigados com hipoclorito de sódio a 1\%. Nos subgrupos em que não se empregou o EDTA, a irrigação final era feita com soro fisiológico. Já, quando se usava o EDTA para a toalete final, a sua aplicação era realizada pelo período de 3 minutos. Após o mesmo, irrigava-se os canais com soro fisiológico e todos os canais foram secos por aspiração e com cones de papel. O EDTA empregado foi de acordo com a fórmula sugerida por Östby ${ }^{65}$ (sal dissódico 17g, água destilada $100 \mathrm{ml}, 5 \mathrm{~N}$ de hidróxido de sódio 9, $25 \mathrm{ml}$, com pH 7,3).

\subsection{2 - Colocação da pasta de hidróxido de cálcio}

A pasta de hidróxido de cálcio utilizada, tanto na forma de curativo como agente cimentante nas obturações pela técnica da condensação lateral foi preparada pela associação de 0,4 $\mathrm{ml}$ de propilenoglicol (medido em seringa descartável de $1 \mathrm{ml}$ ) e $0,560 \mathrm{~g}$ de hidróxido de cálcio P.A. (pró-análise), previamente pesado em uma balança de precisão. Para inserir a pasta no interior dos canais foram empregadas espirais de Lentullo, acionadas àmotor, e a compactação da mesma foi feita com calcadores tipo Paiva e 
bolinhas de algodão. As embocaduras cervicais dos canais foram seladas com Lumicon. O curativo com pasta de hidróxido de cálcio foi mantido por 15 dias. Durante todos os procedimentos operatórios, desde a instrumentação, aplicação de curativo com pasta de hidróxido de cálcio até a obturação, as raízes permaneceram sempre em estufa a $37^{\circ} \mathrm{C} \pm 1$ e ambiente com $100 \%$ de umidade relativa.

\subsection{3 - Obturação dos canais}

Nos dentes em que se empregou a pasta de hidróxido de cálcio, decorridos 15 dias, as raízes foram retiradas da estufa e com o objetivo de remover a pasta, foram reinstrumentados com limas tipo $\mathrm{K} \mathrm{n}$ 's 45 e 30, sob irrigação com 1ml de hipoclorito de sódio a 1\%. Após os canais serem secos com cones de papel, estavam aptos a receber a obturação. Como já foi abordado, usou-se como agentes obturadores, o cimento de óxido de zinco e eugenol e a pasta de hidróxido de cálcio, associados aos cones de guta percha, pela técnica da condensação lateral.

proporcionamento do OZE foi de 1,8 g de óxido de zinco para 1,0 $\mathrm{ml}$ de eugenol seguindo a recomendação de Moraes $^{61}$. Já para a pasta de hidróxido de cálcio, a proporção foi de $0,4 \mathrm{ml}$ de propilenoglicol para 0,560 grs. de hidróxido de cálcio, ou seja, a mesma usada para o curativo. A técnica de obturação (condensação lateral) foi realizada, utilizando-se limas tipo $\mathrm{K} \mathrm{n}^{\circ} 30$ de $21 \mathrm{~mm}$ como espaçadores, de acordo com Bramante et al. ${ }^{11}$, e complementada pela condensação vertical. Quando da obturação, 
para que a técnica pudesse ser realizada em sua plenitude, as raízes foram presas a uma morsa de bancada. Para evitar a remoção da impermeabilização na parte das raízes

onde estas se ajustavam àmorsa, esta foi protegida com borracha de pequena espessura. Após a obturação, com o emprego de um calcador aquecido, cortou-se $2 \mathrm{~mm}$ da massa obturadora. Este espaço era preenchido, posteriormente pelo cimento Lumicon. Em seguida, para aprimorar a impermeabilização coronária e evitar a infiltração do corante, a metade cervical da raiz foi mergulhada em cera rosa derretida.

\subsection{4 - Imersão em corante}

Imediatamente após a obturação, as raízes foram imersas em solução corante de azul de metileno a $2 \%$ tamponado, previamente armazenada em estufa a $37^{\circ} \mathrm{C} \pm 1$, onde permaneceram por 72 horas. Após este período, as raízes foram retiradas do corante e lavadas em água corrente por 12 horas. Para evitar que as raízes fossem removidas dos seus recipientes pela água corrente, tomou-se o cuidado de tampar as aberturas dos mesmos com gaze, que eram presos por elásticos. Este sistema funciona semelhante à uma peneira fina. Após as raízes serem secas, a impermeabilização foi removida com uma lâmina fina, tipo Le Cron. Na seqüência, foram realizados cortes longitudinais nas faces vestibular e palatina das raízes, utilizandose de disco diamantado fino até aproximar-se da obturação. 
Então, as raízes foram fraturadas no seu longo eixo obtendo-se duas hemi-partes nas quais as marcas da infiltração foram medidas a partir da ponta do cone principal, utilizando-se um microcóspio óptico comum munido de uma ocular micrometrada (Técnica da Planimetria). As médias

das infiltrações, medidas em milímetros, foram devidamente tabuladas e submetidas aos testes estatísticos pertinentes.

As figuras 1, 2 e 3, ilustram as secções dentais de alguns espécimes, aleatoriamente distribuídas em função dos subgrupos. 
FIGURA 1 - Fotografias das secções dentais contendo as obturações e as possíveis marcas da infiltração de azul de metileno, distribuídas aleatoriamente em função dos subgrupos 
FIGURA 2 - Fotografias das secções dentais contendo as obturações e as possíveis marcas da infiltração de azul de metileno, distribuídas aleatoriamente em função dos subgrupos 
FIGURA 3 - Fotografias das secções dentais contendo as obturações e as possíveis marcas da infiltração de azul de metileno, distribuídas aleatoriamente em função dos subgrupos 


\section{5 - RESULTADOS}




\section{5 - RESULTADOS}

As extensões da infiltração marginal do azul de metileno a $2 \%$, em milímetros e ao longo das obturações dos canais radiculares, a partir da extremidade apical da obturação, com suas respectivas médias, estão distribuídas nas Tabelas 1, 2 e 3.

A Tabela 4 demonstra a comparação global entre os subgrupos empregando o método não paramétrico de KruskalWallis.

$\mathrm{Na}$ Tabela 5, é feita a comparação individual entre os subgrupos, empregando o teste de Miller. Já a Tabela 6 demonstra a ordenação dos subgrupos, em ordem crescente de infiltração marginal, de acordo com os postos médios encontrados pelo teste de Kruskal-Wallis e as diferenças estatísticas significantes detectadas pelas comparações individuais pelo teste de Miller.

A comparação global da interação entre o momento do emprego do EDTA e o material obturador é feita na Tabela 7. Já na tabela 8 se faz uma comparação entre essas variáveis.

A comparação individual entre o momento do emprego do EDTA e o material obturador é feita na Tabela 9. Já na Tabela 10 encontra-se a ordenação dos subgrupos, em cujos canais se utilizou o EDTA, em ordem crescente de infiltração marginal, de acordo com a Tabela 8 e observando as médias e comparações encontradas na Tabela 9.

$\mathrm{Na}$ Tabela 11, encontra-se a média das infiltrações marginais em mm, em função da variação do momento de emprego do EDTA e da utilização ou não do curativo. Já na 
Tabela 12, se encontram as comparações individuais entre essas variáveis.

A Tabela 13, apresenta a comparação individual entre os materiais obturadores e em relação ao momento do emprego do EDTA.

A comparação global e individual entre a influência do emprego ou não do curativo de hidróxido de cálcio e o tipo de material obturador se encontra nas Tabelas 14 e 15, respectivamente. Já na Tabela 16, a comparação individual se faz em relação àanálise estatística, pelo teste de Tuckey-Kramer.

A Tabela 17 apresenta uma comparação individual entre a presença ou ausência do curativo com a obturação com pasta de hidróxido de cálcio.

A comparação individual entre os materiais obturadores independente da presença ou ausência do curativo de demora, se encontra na Tabela 18.

Essas Tabelas se apresentam distribuídas nas páginas subseqüentes, sendo detalhados os testes estatísticos empregados nessa tese.

No grupo controle negativo não foi observada nenhuma infiltração, enquanto que no grupo controle positivo, a infiltração ocorreu ao longo de todo canal. 
TABELA 1 - Extensão (em mm) da infiltração do azul de metileno a $2 \%$ ao longo das obturações radiculares no Grupo I e as respectivas médias

\begin{tabular}{ccccc}
\hline Dente & $\mathbf{1 . 1}$ & $\mathbf{1 . 2}$ & $\mathbf{2 . 1}$ & $\mathbf{2 . 2}$ \\
\hline 1 & 2,2142 & 1,6190 & 0,4285 & 0.1904 \\
2 & 0,6666 & 0,0000 & 2,2142 & 0,0000 \\
3 & 2,9285 & 1,3809 & 3,2857 & 0,0000 \\
4 & 1,7380 & 0,7857 & 0,9047 & 0,9047 \\
5 & 1,9761 & 0,0000 & 3,5238 & 4,0000 \\
6 & 3,0476 & 0,6666 & 1,3809 & 0,7857 \\
7 & 1,9761 & 0,0000 & 0,0000 & 0,0000 \\
8 & 1,8571 & 0,0000 & 0,1904 & 0,0000 \\
9 & 0,9047 & 0,0000 & 0,3095 & 0,0000 \\
10 & 1,8571 & 0,4285 & 0,0000 & 0,4285 \\
11 & 0,0000 & 0,0000 & 1,5000 & 0,0000 \\
12 & 0,9047 & 0,0000 & 1,8571 & 0,0000 \\
13 & 1,5000 & 0,0000 & 0,1904 & 0,0714 \\
14 & 1,8571 & 1,1428 & 1,9761 & 2,5714 \\
15 & 1,3809 & 0,0000 & 4,9523 & 0,0000 \\
\hline Média & $\mathbf{1 , 6 5 3 9}$ & $\mathbf{0 , 4 0 1 5}$ & $\mathbf{1 , 5 1 4 2}$ & $\mathbf{0 , 5 9 6 8}$
\end{tabular}


TABELA 2 - Extensão (em mm) da infiltração do azul de metileno a $2 \%$ ao longo das obturações radiculares no Grupo II e as respectivas médias

\begin{tabular}{ccccc}
\hline Dente & $\mathbf{1 . 1}$ & $\mathbf{1 . 2}$ & $\mathbf{2 . 1}$ & $\mathbf{2 . 2}$ \\
\hline 1 & 4,0000 & 0,0000 & 0,0000 & 0,1428 \\
2 & 2,8095 & 0,0000 & 0,0000 & 0,0000 \\
3 & 2,0952 & 0,0000 & 0,0000 & 0,0000 \\
4 & 0,5476 & 0,7857 & 0,0000 & 0,0000 \\
5 & 0,4285 & 0,0000 & 0,0000 & 0,0000 \\
6 & 2,5714 & 3,0000 & 0,0000 & 0,0000 \\
7 & 0,4285 & 0,1904 & 1,6190 & 2,8095 \\
8 & 0,9047 & 0,1904 & 0,4285 & 0,6666 \\
9 & 3,0476 & 0,0000 & 0,0000 & 0,0000 \\
10 & 1,3809 & 0,0000 & 0,0000 & 0,0000 \\
11 & 2,5714 & 0,0000 & 0,0000 & 0,9047 \\
12 & 1,8571 & 0,0000 & 0,6666 & 0,0000 \\
13 & 1,3809 & 0,1904 & 0,0000 & 0,9047 \\
14 & 2,3333 & 0,3095 & 0,0000 & 0,0000 \\
15 & 0,0000 & 0,0000 & 0,1904 & 0,3095 \\
\hline Média & $\mathbf{1 , 7 5 7 1}$ & $\mathbf{0 , 3 1 1 0}$ & $\mathbf{0 , 1 9 3 6}$ & $\mathbf{0 , 4 4 9 1}$ \\
\hline & & & &
\end{tabular}


TABELA 3 -Extensão (em mm) da infiltração de azul de metileno a $2 \%$ ao longo das obturações radiculares no Grupo III e as respectivas médias

\begin{tabular}{ccccc}
\hline Dente & $\mathbf{1 . 1}$ & $\mathbf{1 . 2}$ & $\mathbf{2 . 1}$ & $\mathbf{2 . 2}$ \\
\hline 1 & 1,1428 & 0,0000 & 0,0000 & 0,0714 \\
2 & 2,9285 & 0,5476 & 0,0000 & 0,0000 \\
3 & 0,1904 & 0,1904 & 5,1904 & 0,6666 \\
4 & 0,3095 & 0,7857 & 0,0000 & 0,6666 \\
5 & 0,5476 & 0,0000 & 1,8571 & 0,1904 \\
6 & 0,3095 & 1,3809 & 1,3809 & 0,3095 \\
7 & 0,0000 & 0,0714 & 0,9047 & 0,0000 \\
8 & 0,9047 & 0,4285 & 1,0238 & 0,0000 \\
9 & 0,6666 & 1,3809 & 0,6666 & 0,0000 \\
10 & 0,0238 & 0,1904 & 0,5476 & 0,0000 \\
11 & 0,4285 & 0,4285 & 2,8095 & 0,0000 \\
12 & 0,7142 & 0,6666 & 0,6666 & 0,6666 \\
13 & 1,3809 & 0,0000 & 2,3333 & 0,0000 \\
14 & 0,0000 & 1,1428 & 2,5714 & 0,9047 \\
15 & 0,0000 & 0,1904 & 1,6190 & 0,1904 \\
\hline Média & $\mathbf{0 , 6 3 6 4}$ & $\mathbf{0 , 4 9 3 6}$ & $\mathbf{1 , 4 3 8}$ & $\mathbf{0 , 2 4 4 4}$ \\
\hline & & & &
\end{tabular}


TABELA 4 -Comparação global entre os subgrupos pelo teste não paramétrico de Kruskal-Wallis a 5\% (15 espécimes para cada subgrupo)

\begin{tabular}{lrrr}
\hline Subgrupo & \multicolumn{1}{c}{$\begin{array}{l}\text { Soma de } \\
\text { Postos }\end{array}$} & Posto Médio & \multicolumn{1}{l}{$\begin{array}{l}\text { Escore } \\
\text { Médio }\end{array}$} \\
\hline I-1.1 & 2088 & 139,2000 & 1,653913 \\
I-1.2 & 1035,5 & 69,03333 & 0,4015667 \\
I-2.1 & 1803,5 & 120,2333 & 1,51424 \\
I-2.2 & 1090 & 72,6666 & 0,5968066 \\
II-1.1 & 2040,5 & 136,0333 & 1,757107 \\
II-1.2 & 907,5 & 60,5 & 0,3110933 \\
II-2.1 & 793,5 & 52,9 & 0,1936333 \\
II-2.2 & 1042,5 & 69,5 & 0,4491867 \\
III-1.1 & 1397,5 & 93,16666 & 0,6364667 \\
III-1.2 & 1321 & 88,06667 & 0,4936067 \\
III-2.1 & 1779 & 118,6 & 1,43806 \\
III-2.2 & 991,5 & 66,1 & 0,2444134 \\
\hline Valor crítico: 19,68 & & Hc= 59,69992 & p<0,05
\end{tabular}


TABELA 5 -Comparações individuais entre os subgrupos, empregando o teste de Miller

\begin{tabular}{|c|c|c|c|}
\hline \multicolumn{2}{|c|}{$\begin{array}{l}\text { Comparações Valor Observado } \\
\text { Individuais }\end{array}$} & \multirow{2}{*}{$\begin{array}{c}\text { Valor Crítico } \\
62,18\end{array}$} & \multirow{2}{*}{$\frac{\text { Significância }}{\text { N }}$} \\
\hline$\|-2.1 \times\|-1.2$ & 7,6 & & \\
\hline$\|-2.1 \times$ III-2.2 & 13,2 & 62,18 & $\mathrm{~N}$ \\
\hline $\mathrm{II}-2.1 \times \mathrm{I}-1.2$ & 16,13 & 62,18 & $\mathrm{~N}$ \\
\hline$\|-2.1 \times\| \mid-2.2$ & 16,6 & 62,18 & $\mathrm{~N}$ \\
\hline II-2.1 x I-2.2 & 19,76 & 62,18 & $\mathrm{~N}$ \\
\hline$\|-2.1 \times \operatorname{III}-1.2$ & 35,16 & 62,18 & $\mathrm{~N}$ \\
\hline$\|-2.1 \times\|||-1.1$ & 40,26 & 62,18 & $\mathrm{~N}$ \\
\hline II-2.1 x III-2.1 & 65,7 & 62,18 & $S$ \\
\hline$\|-2.1 \times \mid-2.1$ & 67,43 & 62,18 & $S$ \\
\hline$\|-2.1 \times\|-1.1$ & 83,13 & 62,18 & $S$ \\
\hline$I I-2.1 \times I-1.1$ & 86,13 & 62,18 & $S$ \\
\hline$\|-1.2 \times\| I I-2.2$ & 5,6 & 62,18 & $\mathrm{~N}$ \\
\hline$\|-1.2$ x I-1.2 & 8,53 & 62,18 & $\mathrm{~N}$ \\
\hline$\|-1.2 x\|-2.2$ & 9,0 & 62,18 & $\mathrm{~N}$ \\
\hline II-1.2 x I-2.2 & 12,76 & 62,18 & $\mathrm{~N}$ \\
\hline$\|-1.2 \times\| I I-1.2$ & 27,56 & 62,18 & $\mathrm{~N}$ \\
\hline$\|-1.2 \times\| I-1.1$ & 32,66 & 62,18 & $\mathrm{~N}$ \\
\hline$\|-1.2 \times$ III-2.1 & 58,1 & 62,18 & $\mathrm{~N}$ \\
\hline$\|-1.2 \times \mid-2.1$ & 59,73 & 62,18 & $\mathrm{~N}$ \\
\hline$\|-1.2 \times\|-1.1$ & 75,53 & 62,18 & $S$ \\
\hline II-1.2 x I-1.1 & 78,7 & 62,18 & $S$ \\
\hline III-2.2 x I-1.2 & 2,93 & 62,18 & $\mathrm{~N}$ \\
\hline III-2.2 x II-2.2 & 3,4 & 62,18 & $\mathrm{~N}$ \\
\hline III-2.2 x I-2.2 & 6,56 & 62,18 & $\mathrm{~N}$ \\
\hline III-2.2 x III-1.2 & 21,96 & 62,18 & $\mathrm{~N}$ \\
\hline III-2.2 x III-1.1 & 27,16 & 62,18 & $\mathrm{~N}$ \\
\hline III-2.2 x III-2.1 & 52,5 & 62,18 & $\mathrm{~N}$ \\
\hline III-2.2 x I-2.1 & 54,13 & 62,18 & $\mathrm{~N}$ \\
\hline III-2.2 x II-1.1 & 69,93 & 62,18 & $S$ \\
\hline III-2.2 x I-1.1 & 73,1 & 62,18 & $S$ \\
\hline$|-1.2 \times| \mid-2.2$ & 0,47 & 62,18 & $\mathrm{~N}$ \\
\hline$|-1.2 \times|-2.2$ & 3,63 & 62,18 & $\mathrm{~N}$ \\
\hline$|-1.2 x|||-1.2$ & 19,03 & 62,18 & $\mathrm{~N}$ \\
\hline
\end{tabular}


I-1.2 x III-1.1 24,13

62,18

$\mathrm{N}$

TABELA 5 -Comparações individuais entre os subgrupos, empregando o teste de Miller (continuação)

\begin{tabular}{|c|c|c|c|}
\hline$|-1.2 \times|||-2.1$ & 49,57 & 62,18 & $\mathrm{~N}$ \\
\hline$|-1.2 \times|-2.1$ & 51,12 & 62,18 & $\mathrm{~N}$ \\
\hline$|-1.2 \times| \mid-1.1$ & 67 & 62,18 & $S$ \\
\hline$|-1.2 \times|-1.1$ & 70,17 & 62,18 & $S$ \\
\hline $\mathrm{II}-2.2 \times \mathrm{I}-2.2$ & 3,16 & 62,18 & $\mathrm{~N}$ \\
\hline$\|-2.2 \times \operatorname{III}-1.2$ & 18,56 & 62,18 & $\mathrm{~N}$ \\
\hline$\|-2.2 \times \operatorname{II}-1.1$ & 23,66 & 62,18 & $\mathrm{~N}$ \\
\hline II-2.2 x III-2.1 & 49,1 & 62,18 & $\mathrm{~N}$ \\
\hline II-2.2 x I-2.1 & 50,73 & 62,18 & $\mathrm{~N}$ \\
\hline II-2.2 x II-1.1 & 66,53 & 62,18 & $S$ \\
\hline II-2.2 x I-1.1 & 69,7 & 62,18 & $S$ \\
\hline$|-2.2 \times|||-1.2$ & 15,4 & 62,18 & $\mathrm{~N}$ \\
\hline$|-2.2 \times|||-1.1$ & 20,5 & 62,18 & $\mathrm{~N}$ \\
\hline $\mid-2.2 \times$ |II-2.1 & 45,94 & 62,18 & $\mathrm{~N}$ \\
\hline $\mid-2.2$ x I-2.1 & 47,57 & 62,18 & $\mathrm{~N}$ \\
\hline$|-2.2 \times| \mid-1.1$ & 63,37 & 62,18 & $S$ \\
\hline $\mid-2.2$ x I-1.1 & 66,54 & 62,18 & $S$ \\
\hline$|I|-1.2 \times|| \mid-1.1$ & 5,1 & 62,18 & $\mathrm{~N}$ \\
\hline III-1.2 x III-2.1 & 30,54 & 62,18 & $\mathrm{~N}$ \\
\hline III-1.2 x I-2.1 & 32,17 & 62,18 & $\mathrm{~N}$ \\
\hline III-1.2 x II-1.1 & 47,97 & 62,18 & $\mathrm{~N}$ \\
\hline III-1.2 x I-1.1 & 51,14 & 62,18 & $\mathrm{~N}$ \\
\hline III-1.1 x III-2.1 & 25,44 & 62,18 & $\mathrm{~N}$ \\
\hline III-1.1 x I-2.1 & 27,07 & 62,18 & $\mathrm{~N}$ \\
\hline$|I|-1.1 \times||-1.1$ & 42,87 & 62,18 & $\mathrm{~N}$ \\
\hline III-1.1 x I-1.1 & 46,04 & 62,18 & $\mathrm{~N}$ \\
\hline III-2.1 x I-2.1 & 1,63 & 62,18 & $\mathrm{~N}$ \\
\hline III-2.1 x II-1.1 & 17,43 & 62,18 & $\mathrm{~N}$ \\
\hline III-2.1 x I-1.1 & 20,6 & 62,18 & $\mathrm{~N}$ \\
\hline$|-2.1 \times| \mid-1.1$ & 15,8 & 62,18 & $\mathrm{~N}$ \\
\hline$|-2.1 \times|-1.1$ & 18,97 & 62,18 & $\mathrm{~N}$ \\
\hline$\|-1.1 \times \mid-1.1$ & 3,17 & 62,18 & $\mathrm{~N}$ \\
\hline$P<0,05$ & S= Significante & $\mathrm{N}=$ Não significante & \\
\hline
\end{tabular}


TABELA 6 - Ordenação dos subgrupos, em ordem crescente de infiltração marginal de acordo com os postos médios encontrados pelo teste de Kruskal-Wallis a 5\% e as diferenças estatísticas significantes detectadas pelas comparações individuais pelo teste de Miller

\begin{tabular}{|c|c|c|}
\hline Ordem & Subgrupo & Posto Médio \\
\hline $1^{0}$ & II-2.1 EDTA - Curativo - OZE & 52,90000 \\
\hline \multirow[t]{5}{*}{$2^{\circ}$} & II-1.2 EDTA - Curativo - EDTA - Pasta & 60,50000 \\
\hline & III-2.2 Curativo - Pasta & 66,10000 \\
\hline & I-1.2 EDTA - Pasta & 69,03333 \\
\hline & II-2.2. EDTA - Curativo - Pasta & 69,50000 \\
\hline & I-2.2. Pasta & 72,66660 \\
\hline \multirow[t]{2}{*}{$3^{\circ}$} & III-1.2 Curativo - EDTA - Pasta & 88,06667 \\
\hline & III-1.1 Curativo - EDTA - OZE & 93,16666 \\
\hline \multirow[t]{2}{*}{$4^{\circ}$} & III-2.1 Curativo - OZE & 118,60007 \\
\hline & $\mathrm{I}-2.1 \mathrm{OZE}$ & 120,2333 \\
\hline \multirow[t]{2}{*}{$5^{\circ}$} & II-1.1 EDTA - Curativo - EDTA - OZE & 136,0333 \\
\hline & I-1.1. EDTA - OZE & 139,2000 \\
\hline
\end{tabular}


TABELA 7 -Comparação global pelo teste ANOVA a 2 critérios, em nível de $5 \%$ de significância entre o momento do emprego do EDTA e o material obturador

\begin{tabular}{lccc}
\hline Fonte de variação & $\begin{array}{c}\text { Soma de } \\
\text { Quadrados }\end{array}$ & $\begin{array}{c}\text { Graus de } \\
\text { Liberdade }\end{array}$ & $\begin{array}{c}\text { Quadrado } \\
\text { Médio }\end{array}$ \\
\hline Entre EDTA & 11,25254 & 3 & 3,750847 \\
Entre Material & 12,53564 & 1 & 12,53564 \\
Entre EDTA x Material & 15,55218 & 3 & 5,184059 \\
Resíduo & & & \\
\hline Variação total & $\mathbf{1 0 2 , 7 7 5 8}$ & $\mathbf{1 1 9}$ & \\
\hline
\end{tabular}


TABELA 8 - Valores médios e desvio padrão dos subgrupos em função do uso do EDTA e o material obturador

\begin{tabular}{|c|c|c|c|}
\hline EDTA / Curativo & $\begin{array}{c}\text { Material } \\
\text { Obturador }\end{array}$ & Média & $\begin{array}{l}\text { Desvio } \\
\text { Padrão }\end{array}$ \\
\hline Antes & OZE & 0,1936333 & 0,4410194 \\
\hline Antes & Pasta & 0,4491867 & 0,7722815 \\
\hline Após & OZE & 0,6364667 & 0,7652001 \\
\hline Após & Pasta & 0,4936067 & 0,4860683 \\
\hline Antes/Após & OZE & 1,757107 & 1,154999 \\
\hline Antes/Após & Pasta & 0,3110934 & 0,7732208 \\
\hline Sem curativo/Antes & OZE & 1,653913 & 0,8084593 \\
\hline Sem curativo/Antes & Pasta & 0,4015667 & 0,5769683 \\
\hline
\end{tabular}


TABELA 9 -Comparações individuais pelo teste de Tuckey-Kramer em função do momento do emprego do EDTA e o material obturador

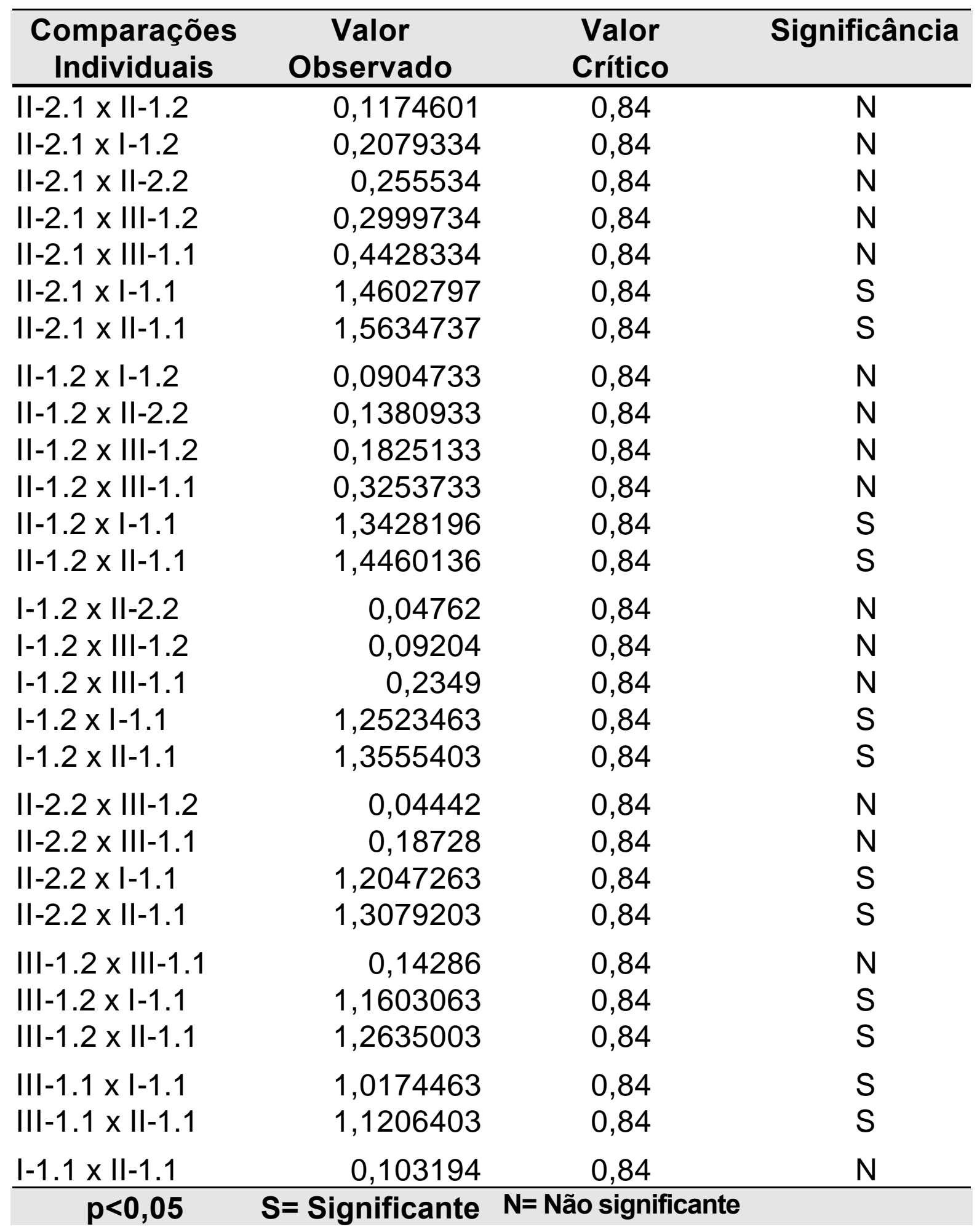


TABELA 10 -Ordenação dos subgrupos, em cujos canais se utilizou o EDTA, em ordem crescente de infiltração marginal, de acordo com os dados da Tabela 8, observando-se as médias, e as comparações na Tabela 9

\begin{tabular}{|c|c|c|}
\hline Ordem & Subgrupo & Média \\
\hline \multirow[t]{6}{*}{$1^{0}$} & II-2.1 EDTA - Curativo - OZE & 0,1936 \\
\hline & II-1.2 EDTA - Curativo - EDTA - Pasta & 0,3110 \\
\hline & I-1.2 EDTA - Pasta & 0,4015 \\
\hline & II-2.2. EDTA - Curativo - Pasta & 0,4491 \\
\hline & III-1.2 Curativo - EDTA - Pasta & 0,4936 \\
\hline & III-1.1 Curativo - EDTA - OZE & $0,6364-$ \\
\hline \multirow[t]{2}{*}{$2^{0}$} & I-1.1 EDTA - OZE & 1,6539 \\
\hline & II-1.1 EDTA - Curativo - EDTA - OZE & 1,7571 \\
\hline
\end{tabular}


TABELA 11 - Média das infiltrações marginais em mm, em função da variação do emprego do EDTA e da utilização ou não do curativo

\begin{tabular}{lcr}
\hline \multicolumn{1}{c}{ EDTA } & CURATIVO & \multicolumn{1}{c}{ MÉDIA } \\
\hline Antes & Sim & 0,32141 \\
Após & Sim & 0,565036 \\
Antes/Após & Sim & 1,0341 \\
& & 1,02774 \\
Presente & Não & \\
\hline
\end{tabular}


TABELA 12 - Comparação individual pelo teste de TuckeyKramer, em função do momento de emprego do EDTA e da presença ou não do curativo

Comparações Valor Observado Valor Crítico Significância Individuais
$A^{*} \times B^{* *}$
$0,24362 \quad 0,5070$
N

$A \times C^{* \star *}$

0,70633

0,5070

S

$A \times D^{* * * *}$

0,71269

0,5070

S

$\mathrm{B} \times \mathrm{C}$

$0,4627 \quad 0,5070$

$\mathrm{N}$

$B \times D$

$0,46906 \quad 0,5070$

$\mathrm{N}$

C x D

0,00636

0,5070

N

* A - EDTA antes do curativo - 0,32141

** B - EDTA após o curativo - 0,5650366

*** C - EDTA antes/após curativo - 1,02774

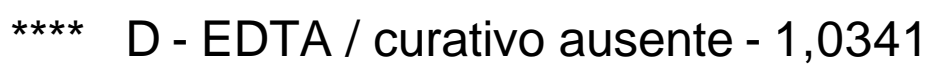


TABELA 13 - Comparação individual pelo teste de TuckeyKramer, entre os materiais obturadores, com relação ao momento de emprego do EDTA

\begin{tabular}{|c|c|c|c|c|}
\hline OZE & Pasta & Valor Observado & Valor Crítico & Significância \\
\hline \multirow[t]{2}{*}{1,06028} & 0,41386 & 0,6464167 & 0,272 & $\bar{s}$ \\
\hline & 3 & & & \\
\hline & & $p<0,05$ & S= Significan & \\
\hline
\end{tabular}


TABELA 14 - Comparação global pelo teste ANOVA a 2 critérios em função do material obturador e o emprego do EDTA

\begin{tabular}{lccc}
\hline Fonte de Variação & $\begin{array}{c}\text { Soma de } \\
\text { Quadrados }\end{array}$ & $\begin{array}{c}\text { Graus de } \\
\text { Liberdade }\end{array}$ & $\begin{array}{c}\text { Quadrado } \\
\text { Médio }\end{array}$ \\
\hline EDTA & 11,25254 & 3 & 3,750847 \\
Material & 12,53564 & 1 & 12,53564 \\
EDTA x Material & 15,55218 & 3 & 5,184059 \\
Resíduo & & 112 & 0,5663876 \\
Variação total & 102,7758 & 119 & \\
\hline p<0,05 & 63,43542 & &
\end{tabular}


TABELA 15 - Média da infiltração e desvio padrão em função da presença do curativo e do material obturador

\begin{tabular}{lcrr}
\hline Curativo & Material Obturador & Média & Desvio Padrão \\
\hline Ausente & OZE & 1,653913 & 0,8084593 \\
Ausente & Pasta & 0,4015667 & 0,5769683 \\
Presente & OZE & 0,1936333 & 0,4410194 \\
& & & \\
Presente & Pasta & 0,4491867 & 0,7722815 \\
\hline $\mathbf{p}<\mathbf{0 , 0 5}$ & & &
\end{tabular}


TABELA 16 - Comparação individual, pelo teste de TuckeyKramer, da influência do emprego ou não do curativo e o tipo do material obturador

\begin{tabular}{|c|c|c|c|c|}
\hline $\begin{array}{c}\text { Comparações } \\
\text { Individuais }\end{array}$ & Valor Observado & Valor Crítico & Sig & ificância \\
\hline$A^{*} \times B^{\star *}$ & 1,2523463 & 0,910 & & $S$ \\
\hline$A \times C^{* * *}$ & 1,4602797 & 0,910 & & $S$ \\
\hline$A \times D^{* * * *}$ & 1,2047263 & 0,910 & & $S$ \\
\hline $\mathrm{B} \times \mathrm{C}$ & 0,2079334 & 0,910 & & $S$ \\
\hline$B \times D$ & 0,0476200 & 0,910 & & $S$ \\
\hline \multirow[t]{2}{*}{$C \times D$} & 0,2555534 & 0,910 & & $\mathrm{~N}$ \\
\hline & $p<0,05$ & $\mathrm{~S}=$ significante & $\mathrm{N}=\mathrm{Nã}$ & significante \\
\hline * & Curativo & Material Obtu & rador & \\
\hline$A^{*}$ & Ausente & OZE & & \\
\hline $\mathrm{B}^{\star \star}$ & Ausente & Pasta & & \\
\hline $\mathrm{C}^{* * *}$ & Presente & OZE & & \\
\hline$D^{\star * * *}$ & Presente & Pasta & & \\
\hline
\end{tabular}


TABELA 17 - Comparação individual, pelo teste de TuckeyKramer, entre a presença ou ausência do curativo com pasta de hidróxido de cálcio, independente do material obturador

\begin{tabular}{|c|c|c|c|c|c|}
\hline $\begin{array}{c}\text { Comparaçã } \\
0\end{array}$ & $\begin{array}{l}\text { Curativo } \\
\text { Presente }\end{array}$ & $\begin{array}{l}\text { Curativo } \\
\text { Ausente }\end{array}$ & $\begin{array}{c}\text { Valor } \\
\text { Observado }\end{array}$ & $\begin{array}{l}\text { Valor } \\
\text { Crítico }\end{array}$ & Significância \\
\hline \multicolumn{6}{|l|}{ Curativo } \\
\hline \multicolumn{6}{|l|}{ Presente } \\
\hline$X$ & 0,32141 & 1,02774 & 0,70633 & 0,3444 & $S$ \\
\hline \multicolumn{6}{|l|}{ Curativo } \\
\hline \multicolumn{6}{|l|}{ Ausente } \\
\hline$p<0,0$ & & $\mathrm{~S}=\mathrm{S}$ & ignificante & & \\
\hline
\end{tabular}


TABELA 18 - Comparação individual, pelo teste de TuckeyKramer, entre ao materiais obturadores, independente da presença ou ausência do curativo de demora

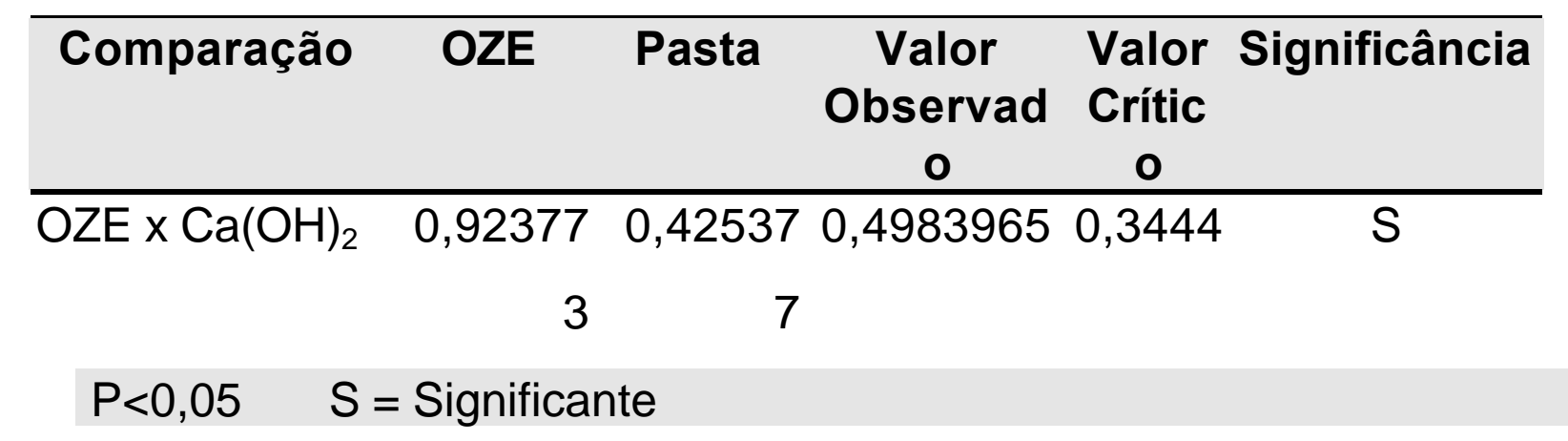




\section{6 - DISCUSSÃO}




\section{6 - DISCUSSÃO}

A preocupação com a qualidade do tratamento endodôntico já pode ser detectada claramente em um clássico trabalho de INGLE ${ }^{44}$ em 1961, quando ele realizou uma análise dos sucessos e insucessos dos tratamentos endodônticos realizados no departamento de Endodontia da Universidade de Washington. Foram detectadas falhas no tratamento endodôntico em 5,55\% dos casos analisados. Deste percentual, a incorreta obturação dos canais radiculares era responsável por 58,65\% das falhas. A partir destas observações o autor propôs uma estandardização de normas e instrumentos, com o intuito de simplificar a conduta clínica e produzir uma minimização dos erros.

O completo preenchimento do sistema de canais radiculares é um aspecto muito importante para se obter sucesso no tratamento endodôntico. A qualidade do selamento apical depende de vários fatores, entre eles: preparo químico-mecânico (irrigação-instrumentação), tipo de cimento obturador e técnica de obturação (PORKAEW ${ }^{70}$ ). Segundo HOLLAND; MURATA ${ }^{37}$ e PORKAEW ${ }^{70}$, curativos de demora com hidróxido de cálcio poderiam, também, melhorar o selamento apical das obturações de canais radiculares. 


\section{1 - Da Metodologia}

\subsection{1 - Seleção e preparo dos dentes}

Com o objetivo de facilitar o acesso e a instrumentação dos canais, eliminou-se a coroa dos dentes utilizados neste trabalho. Posteriormente, foi feita a medida do comprimento das raízes, sendo utilizadas, apenas as que mediam entre 11 a $13 \mathrm{~mm}$. Essa padronização é importante, pois de acordo com ISHLEY ${ }^{45}$, quanto maior for a raiz, maior será a área para atuação do corante e, principalmente, cria dificuldades para o preparo químicomecânico. Assim, consegue-se diminuir as interferências desta variável, ou seja, tamanho da raiz, que poderia influenciar, nos resultados.

No tratamento dos canais radiculares, inúmeras pesquisas citadas na literatura diferenciam-se pela escolha das técnicas de instrumentação ${ }^{56,70}$, materiais obturadores , $^{1,3,7,20,26,36,47,53,75}$ e técnicas de obturação 3,7,10,20,26,34,35,37,41,42,47,53,54,69,70,75.

Quando da instrumentação dos canais, procurou-se padronizar o diâmetro do forame apical, dilatando-o em todo o seu comprimento até a lima $n^{\circ}$ 30. Com esta manobra, a área de acesso do corante na marcação da infiltração apresentava o mesmo diâmetro para todos os dentes. As limas de $n^{\circ}=35,40$ e 45 atuaram com comprimento de trabalho $1 \mathrm{~mm}$ menor do que a lima $n \cong 30$, com o objetivo de criar o degrau apical, facilitando uma boa adaptação do cone principal e por conseqüência uma 
obturação dentro dos limites desejados, ou seja, a $1 \mathrm{~mm}$ do forame apical.

Para minimizar a possibilidade de erros, devido ao cansaço, foram instrumentados 15 dentes por dia. Esta conduta foi adotada, com o objetivo de diminuir a interferência desta variável, que poderia induzir a variações na análise estatística.

A impermeabilização dos dentes, empregando o araldite é amplamente empregada, sendo a sua eficiência comprovada por inúmeros trabalhos ${ }^{1,3,7,10,17,35,36,37,39,40,41,53,70}$. Há de ressaltar que neste trabalho foram usados duas camadas de araldite, com 0 objetivo de aumentar a confiabilidade da impermeabilização. Atenção especial foi tomada para se evitar a obstrução do forame apical, com o material impermeabilizador.

Para determinação da consistência da pasta de hidróxido de cálcio, foram feitos vários testes piloto, até se chegar a fórmula de 0,4 $\mathrm{ml}$ de propilenoglicol associado a 0,560 $\mathrm{g}$ de pó de hidróxido de cálcio P.A. Estas medidas foram determinadas quando se conseguiu uma pasta que apresentava boa consistência, formando um fio que se rompia a aproximadamente 2 $\mathrm{cm}$ quando se removia da placa de vidro uma espátula envolta no material.

Em relação ao tempo de permanência do curativo de hidróxido de cálcio no interior de canais, alguns aspectos importantes foram salientados por vários autores. Já em 1981, TRONSTAD et al. ${ }^{78}$, na análise da difusão de íons hidroxila do curativo de hidróxido de cálcio e avaliando as variações de $\mathrm{pH}$, 
observaram alterações na área de reabsorção, com interferências na atividade osteoclástica e no processo de reparo, quando do preenchimento dos canais por 4 semanas. Já SJÖGREN et al. ${ }^{74}$ em 1991, testando o efeito antibacteriano do hidróxido de cálcio, demonstraram que após o preparo biomecânico poderá haver permanência de microorganismos, sendo a efetividade deste fármaco confiável em um período mínimo de 7 dias. $F A V A^{21}$, em 1983, analisando o poder antibacteriano do curativo de hidróxido de cálcio, recomendou um tempo maior na sua permanência, para que possa haver liberação de íons hidroxila e a alcalinização do meio. NERWICH et al. ${ }^{62}$, em 1993, desejando avaliar o tempo necessário para que o $\mathrm{pH}$ da dentina em contato com curativo de hidróxido de cálcio aumentasse seu valor, deduziram que o aumento do $\mathrm{pH}$ na dentina interna é mais rápido do que na dentina externa, sendo um tempo ideal de permanência do curativo entre 2 a 3 semanas. Em 1996, GOMES et al. ${ }^{28}$, investigando a difusão dos íons cálcio da pasta curativa de hidróxido de cálcio no interior do canal radicular, observaram que sua concentração máxima demora entre 2 a 3 semanas para ser atingida. Também em 1996, TAKAHASHI et al. $^{77}$ demonstraram que para que o curativo de hidróxido de cálcio no interior do canal seja eficaz, é necessário um período de pelo menos 2 semanas.

Já SILVEIRA ${ }^{73}$, em 1997, demonstrou que a permanência do curativo de hidróxido de cálcio no interior dos canais radiculares, por um período de 15 dias, mostrou-se mais eficaz do que 7 dias e próximo dos resultados encontrados quando empregado por 30 dias, porém sendo menos eficaz do que este. 
Levando em consideração todas essas análises anteriores e mantendo o objetivo de se aproximar o máximo possível da realidade e viabilidade clínica, optou-se por 15 dias como sendo um tempo razoável na aplicação do curativo de demora do hidróxido de cálcio.

Uma preocupação que se teve neste trabalho quando da manipulação do cimento, foi procurar uma padronização para todos os espécimes. A presença de variáveis como temperatura, umidade e tempo de endurecimento, podem interferir nas propriedades do cimento $\left(\right.$ ISHLEY $\left.^{45}\right)$. O proporcionamento pó/líquido proposto foi rigorosamente seguido.

Como técnica de obturação, a opção foi pela técnica da condensação lateral. Esta técnica é a mais comumente empregada na odontologia $3,7,10,20,26,34,35,37,41,42,51,54,69,70,75$. Além de apresentar uma grande facilidade na sua execução, apresenta resultados bastante satisfatórios.

A manutenção dos dentes em estufa a $37^{\circ} \mathrm{C}$ e ambiente com $100 \%$ de umidade relativa foi utilizada para tentar reproduzir as condições clínicas. Dentro desta linha de conduta, os dentes foram colocados em contato com o corante, imediatamente após a obturação.

Um número muito variável de métodos tem sido empregado para determinar a infiltração após a obturação dos canais radiculares. Dentre os citados na literatura destacam-se os seguintes: utilização dos corantes marcadores $1,4,10,17,20,35,37,40,42,49,53,54,60,69,70,71,75,76$, radioisótopos ${ }^{4}$, presença de microorganismos ${ }^{4,26}$, presença de dispositivos 
impulsionadores de $\mathrm{ar}^{84}$, modelos adaptados para transporte de fluidos $^{4,49,84}$. De todos estes métodos, os corantes são os mais empregados, sendo a solução de azul de metileno a mais utilizada $^{1,17,35,36,37,40,42,43,49,53,54,60,70,71,76,84}$, especialmente pelo seu baixo peso molecular ${ }^{1,49,54}$, o que facilita a sua difusão e penetração nos túbulos dentinários e canais acessórios.

Pesquisas que usam o azul de metileno para determinar a infiltração das obturações dos canais radiculares, podem apresentar variações ou resultados conflitantes, apesar de empregarem metodologias similares. Neste caso, esta situação se explica pelo fato do corante poder se descolorir ou marcar com menos intensidade, devido ao contato com 0 material testado $^{16,49,58,84}$. Conseqüentemente, a penetração da solução por estar sofrendo um processo de descoloração ou mesmo de inativação, pode não ser detectada ao longo da obturação, sendo pois determinado uma medida irreal da penetração do corante, isto é, um resultado falso negativo.

Apesar do grande número de publicações científicas que empregam corantes como marcadores de infiltração, os fatos citados anteriormente, mesmo sendo de fundamental importância na análise dos resultados encontrados, infelizmente, são pouco citados na literatura, segundo WU ${ }^{84}$, em 1998.

A área de contato do material obturador com o corante, bem como o volume do mesmo presente em um recipiente são de fundamental importância na intensidade da descoloração do marcador. O aumento da área de contato em um volume pequeno 
de corante, poderá intensificar a descoloração, diminuindo assim, a capacidade marcadora do mesmo $\left(\mathrm{WU}^{84}\right)$.

Mesmo sendo a solução de azul de metileno amplamente empregada como traçadora de infiltrações dentais, como já foi mencionado, pouco se conhece a respeito da reação entre o azul de metileno e vários materiais testados ${ }^{84}$.

Estudando textos que discorrem sobre as propriedades do azul de metileno ${ }^{49,51,58}$, foi encontrado que este pode sofrer alterações de redução quando em contato com substâncias redutoras $^{16,49,58,84}$, podendo, pois começar a descolorir e marcar com menos intensidade. Outra propriedade muito importante é a incompatibilidade do azul de metileno com substâncias alcalinas entre as quais, o hidróxido de cálcio ${ }^{16,49,51,58}$.

Para a leitura das medidas das infiltrações marginais do corante azul de metileno a $2 \%$ ao longo das raízes, foi empregado o microscópio óptico munido de uma ocular micrometrada, metodologia similar a empregada por vários outros autores $^{1,7,17,37,40,41,42,43,47,54,70,75,76}$.

\section{2 - Dos Resultados}

A compilação dos resultados com significância estatística das comparações individuais encontrados na Tabela 5 permitiu a confecção de uma ordenação das variáveis experimentais (subgrupos) partindo daquela que apresentou a menor magnitude de infiltração marginal para aquela que propiciou a maior, gerando a Tabela 6. 
A análise detalhada desta Tabela permite definir a interferência do hidróxido de cálcio sobre a infiltração marginal, seja na forma de curativo ou como material obturador. A menor magnitude de infiltração observada foi propiciada pelo subgrupo II$2.1(0,1936 \mathrm{~mm})$ cujos canais receberam a aplicação de EDTA por 3 minutos imediatamente após o preparo químico-mecânico e antes do curativo com pasta de hidróxido de cálcio com propilenoglicol por 15 dias para, então, serem obturados com cimento de óxido de zinco e eugenol (OZE). Este resultado está de pleno acordo com aqueles

encontrados por outros autores. É interessante ressaltar que este grupo se diferenciou estatisticamente de outros quatro cujos canais foram obturados com o mesmo cimento (III-2.1, I-2.1, I-1.1. e II-1.1).

Inclusive, dois desses subgrupos (III-2.1 e II-1.1) tiveram seus canais preenchidos com pasta de hidróxido de cálcio como curativo, diferenciando-se apenas pela não aplicação do EDTA no subgrupo III-2.1 e a sua reaplicação após o curativo no subgrupo II-1.1.

Quando a comparação é feita entre os materiais obturadores (Tabela 18) destaca-se uma diferenciação estatística a favor das obturações realizadas com a pasta de hidróxido de cálcio. Inclusive, mesmo quando se analisa os resultados em função dos tratamentos aplicados aos canais radiculares (Tabelas 9 e 10) fica evidente a supremacia da pasta de hidróxido de cálcio sobre o cimento de óxido de zinco e eugenol. Ressalte-se, ainda, que o melhor resultado obtido neste trabalho aconteceu no 
subgrupo obturado com OZE, porém, seus canais receberam aplicação de EDTA após o preparo químico-mecânico e curativo com pasta de hidróxido de cálcio antes da obturação. A Tabela 6, também, permite observar que dos 7 subgrupos melhores posicionados, 6 deles foram obturados com pasta de hidróxido de cálcio.

Levando-se em consideração as conclusões de HOLLAND $^{39,40,41,42}$ e HOLLAND; MURATA ${ }^{37}$ de que o curativo de hidróxido de cálcio, anteriormente à obturação com cimento de óxido de zinco e eugenol, levaria à uma melhora na capacidade seladora do mesmo, este fato fica evidente quando se considera os resultados propiciados pelas obturações do subgrupo II-2.1 (EDTA-

Curativo-OZE), que foram as que permitiram menor infiltração inclusive, diferenciando-se estatisticamente de outros 4 subgrupos obturadores com o mesmo OZE. Contudo, o que dizer dos resultados dos subgrupos obturados com a pasta de hidróxido de cálcio e propilenoglicol? As pastas, em geral, sempre foram utilizadas na Endodontia como materiais provisórios; atuando mais especificamente como curativos de demora. Sem dúvida, a utilização da pasta de hidróxido de cálcio com propilenoglicol como material obturador definitivo, juntamente com cones de gutapercha (condensação lateral) neste trabalho, fugiu das condições normais de seu uso, contrariando, inclusive, alguns preceitos observados na endodontia.

Com certeza, a pasta não possui aquelas propriedades físicas exigidas de um material obturador de canais radiculares. 
Pelas suas características é óbvio deduzir que o selamento físico propiciado por ela seria bastante deficiente. Segundo DE DEUS ${ }^{18}$, um material obturador de canal deveria possuir dentre outras, as seguintes propriedades físicas: selar lateral e apicalmente o canal; não sofrer retração após o seu endurecimento; ser impermeável à umidade e insolúvel, quando no interior da cavidade pulpar, nos limites próprios da obturação; ser homogêneo, quando manipulado, a fim de promover boa adesividade, quando obtida sua presa, entre ele e as paredes do canal; ser insolúvel frente aos fluidos teciduais. Percebe-se claramente, que a pasta de hidróxido de cálcio não possui essas propriedades. Então, como se explicaria os bons resultados proporcionados pelas obturações com ela executadas? A interação dos resíduos do curativo de hidróxido de cálcio com o cimento OZE, melhorando o selamento segundo HOLLAND; MURATA ${ }^{37}$ provavelmente, deve ter ocorrido quando se analisa o subgrupo II-2.1 e mesmo o III-1.1. Todavia, em função dos resultados obtidos com as obturações com a pasta, com certeza, outros fatores devem ter colaborado para ocorrência do mesmo. A idéia de que o hidróxido de cálcio poderia penetrar nos túbulos dentinários, obliterando-os fisicamente, conforme afirmações de BERGENHOLTZ ${ }^{9}$, não parece ser a mais correta. Outros autores ${ }^{21,62,78}$ têm destacado 0 poder de alcalinização da dentina pelo hidróxido de cálcio, fato este que, segundo MORAES ${ }^{*}$, talvez seja o principal fator a ser levado em consideração para a interpretação dos bons resultados obtidos com obturações que foram realizadas com cimentos de 
hidróxido de cálcio ou cujos canais tenham recebido qualquer tratamento alcalinizante. Já PORKAEW ${ }^{70}$, aventou a possibilidade do hidróxido de cálcio reagir, originando o carbonato de cálcio. Contudo, este pode sofrer reabsorções e, à longo prazo, criar espaços na interface obturação-paredes do canal.

Outro fator que poderia mascarar a infiltração marginal ocorrida seria a descoloração da solução de azul de metileno observada por KONKATIOTIS ${ }^{49}$, WU ${ }^{84}$. Embora, não se possa duvidar de que, realmente, este tipo de problema ocorra; em virtude dos resultados obtidos neste trabalho, principalmente com a pasta e, pela própria observação do comportamento das obturações durante o corte e preparo dos espécimes para a leitura da infiltração, percebeu-se que em alguns casos, a solução de azul de metileno havia penetrado na massa da obturação com a pasta, contudo, a

dentina encontrava-se isenta de marcação pela solução corante. Portanto, pode se acreditar que deva ocorrer alguma interação química entre o hidróxido de cálcio e a dentina e, se não, entre o hidróxido de cálcio e a solução de azul de metileno, de maneira que a dentina não sofra marcação pelo corante, ficando como que impermeabilizada a ele. É fato notório que o azul de metileno pode sofrer alterações de redução quando em contato com substâncias redutoras ${ }^{16,49,58,84}$, podendo assim, começar a se descolorir e a marcar com menor intensidade. Outra propriedade muito importante é a incompatibilidade do azul de metileno com substâncias alcalinas, como é o hidróxido de cálcio ${ }^{16,49,51,58}$. 
A definição clara e objetiva da melhor performance das obturações realizadas com pasta de hidróxido de cálcio ainda não teve a sua causa definida neste trabalho. Outras pesquisas fazemse necessárias para tentar elucidar essas interrogações.

Quanto à utilização do EDTA, na endodontia, ele tem o seu uso consagrado na eliminação da lama dentinária (smear-layer) após 0 preparo químico-mecânico dos canais radiculares $8,12,15,23,25,27,29,34,35,46,48,52,57,64,71,85$. Alguns trabalhos sugerem que ela seria suficiente para impedir um melhor selamento das obturações dos canais. A lama ou magma dentinária é constituída de um componente inorgânico, representado por restos de dentina e por um orgânico de tecido pulpar vital ou necrosado, prolongamentos odontoblásticos, bactérias e células sangüíneas (GOLDMAN ${ }^{27}, \mathrm{MCCOMB}^{57}$ ).

Quando da instrumentação dos canais radiculares, estes componentes podem ficar em suspensão e vão se acumulando no interior do conduto, especialmente no terço apical. Por ação mecânica dos instrumentos, eles podem ser compactados contra as paredes do canal radicular penetrando, inclusive, nos túbulos dentinários, podendo criar uma interface entre o material obturador e a parede de dentina $20,40,52,72$. É provável que com o passar do tempo, o seu volume seja instável, principalmente devido seu alto conteúdo de água, a qual não seria eliminada, mesmo com "efetiva" secagem do canal.

A eliminação da smear-layer deve ser tentada, pois a sua permanência pode originar as seguintes complicações ${ }^{8,15,24,33,60}$ : 
a) pode servir de abrigo a microorganismos, ou mesmo selá-los no interior dos túbulos dentinários;

b) impedir ou dificultar a ação de medicamentos empregados como curativo entre as sessões;

c) prejudicar a qualidade da obturação dos canais radiculares, pois poderá ocupar o espaço do material obturador;

d) atuar como agente flogógeno.

Assim, percebe-se que sua remoção é um fator muito importante, principalmente em casos de necrose pulpar.

No tratamento de dentes com necrose pulpar, notadamente nos portadores de lesões periapicais, existem ramificações do canal principal que podem se apresentar contaminadas. Além da dificuldade ou mesmo na impossibilidade de se ter acesso à essas ramificações com os instrumentos endodônticos, poderá ocorrer durante o preparo químicomecânico do canal, penetração do magma dentinário na embocadura dos túbulos dentinários, obstruindo a comunicação com o canal principal. Empregando-se o EDTA, haverá a possibilidade de se conseguir a remoção destas obstruções, o que facilitará o preenchimento das ramificações com os cimentos obturadores ou mesmo com a guta-percha, quando se emprega a termoplastificação como técnica obturadora. $\left(\right.$ HOLLAND $\left.^{34}\right)$.

A observação da Tabela 10 permite fazer algumas interpretações da influência do uso do EDTA frente aos materiais obturadores. Se a análise for feita de acordo com os materiais 
obturadores percebe-se que a sua utilização não foi capaz de causar diferença no selamento, digna de nota. O que se viu foi que as obturações com pasta permitiram pequenas infiltrações e as com OZE, maiores. Todavia, algumas considerações necessitam ser feitas, principalmente, quanto ao momento da aplicação do EDTA. Pelos resultados dos vários testes estatísticos (Tabelas 6 e 10) fica evidentíssimo o efeito benéfico da utilização do EDTA antes da colocação do curativo com pasta de hidróxido de cálcio nas obturações com cimento de óxido de zinco e eugenol (subgrupo II-2.1). Em contra partida fica claro que o EDTA não deve ser reaplicado após o curativo como bem demonstram os resultados do subgrupo II-1.1 (Tabela 10). Dentro dos grupos, cujos canais foram obturados com a pasta, o que se nota é que a utilização do EDTA não teve qualquer influência sobre os resultados; a infiltração foi sempre de pequena monta.

Voltando a considerar as obturações realizadas com cimento de óxido de zinco e eugenol, novas deduções podem ser feitas quanto àação do EDTA; principalmente quando da interação com o curativo de hidróxido de cálcio. A Tabela 10 evidencia que, além do excelente resultado proporcionado pelo subgrupo II-2.1 (EDTA - curativo - OZE, $1^{0}$ colocado na Tabela 6) também o subgrupo III-1.1 (curativo - EDTA - OZE) se destacou com diferenciação estatística dos subgrupos l-1.1 (EDTA - OZE) e II1.1 (EDTA - curativo - EDTA - OZE). Esses dados permitem deduzir, aqui, o efeito benéfico do curativo de hidróxido de cálcio e que após o mesmo não se deve fazer a reaplicação do EDTA (subgrupo II-1.1). 
Os dados das Tabelas 5 e 6 mostram que existe diferença estatística significante entre o subgrupo $1^{\circ}$ colocado (II2.1 - EDTA - Curativo - OZE) e $04^{\circ}$ e $5^{\circ}$ colocados (III- 2.1 Curativo - OZE, I-2.1 - OZE, II-1.1 - EDTA - Curativo - EDTA OZE e 1-1.1- EDTA - OZE). Percebe-se que o único subgrupo daqueles obturados com OZE, além de todos com pasta, que não se diferenciou estatisticamente do $1^{\circ}$ colocado (subgrupo II-2.1) foi o subgrupo III-1.1 (curativo - EDTA - OZE). Entre esses dois subgrupos a diferença está apenas no momento da aplicação do EDTA. Pela performance marcante do subgrupo II-2.1 é evidente que aquela seqüência clínica deva ser a escolhida. $\mathrm{Na}$ interpretação desses resultados algumas deduções, ainda, podem ser feitas. A remoção da lama dentinária deve ser de grande importância para que o hidróxido de cálcio possa atuar plenamente sobre as paredes de uma dentina estruturada, livre de detritos. Quando da aplicação do curativo sobre a lama dentinária (sem a aplicação prévia de EDTA, subgrupo III-1.1) provavelmente, a alcalinização daquela dentina estruturada não deve ter ocorrido em grande profundidade, contudo, após a remoção do curativo, a lama ainda, deve ter persistido e a aplicação do EDTA (subgrupo III-1.1) não foi suficiente para removê-

la, bem como, todo o resíduo da ação do hidróxido de cálcio. Daí, o curativo manteve seu efeito benéfico em impedir a marcação do azul de metileno.

No subgrupo II-1.1 (EDTA - Curativo - EDTA - OZE), com certeza, a aplicação do EDTA foi suficiente para remover toda 
a lama dentinária como demonstram vários autores $^{8,12,15,23,25,27,29,34,35,46,48,52,57,64,71,85}$. Quando da colocação do curativo do hidróxido de cálcio, o mesmo deve ter entrado em contato direto com a dentina estruturada, como no caso do subgrupo II-2.1 (EDTA - Curativo - OZE). Porém, com a reaplicação do EDTA, este deve ter eliminado aquele efeito benéfico do hidróxido de cálcio, o que permitiu que a marcação ocorresse com maior intensidade.

\section{3 - Considerações gerais}

Este trabalho foi realizado dentro de condições que fogem um tanto da realidade clínica no que tange àobturação dos canais radiculares, para determinados subgrupos, com pasta de hidróxido de cálcio à guisa de cimento obturador. $\mathrm{O}$ que se objetivou com este procedimento foi tentar comprovar a suspeita de MORAES ${ }^{*}$ de que a menor infiltração observada em canais obturados com cimentos que contêm hidróxido de cálcio ou, mesmo com cimento de óxido de zinco e eugenol, porém que, anteriormente àobturação haviam recebido curativo com hidróxido de cálcio, não se deve apenas àboa capacidade seladora daquele primeiro cimento ou a uma melhoria nas propriedades de selamento do óxido de zinco e eugenol; isto é, que a causa da menor infiltração não estaria relacionada apenas aos requisitos físicos, mas também a outras alterações, provavelmente de 
natureza química. As hipóteses aventadas por $\mathrm{WU}^{84}$ de que a marcação da dentina não ocorreria devido à descoloração da solução de azul de metileno também podem ser levadas em consideração, contudo, elas não explicam de maneira definitiva aquela ocorrência. As condições a que foram submetidas as obturações neste experimento, diferem em muito daquelas relatadas por aqueles autores. MORAES ${ }^{61}$, encontrou infiltrações de azul de metileno em obturações com cimentos que contém hidróxido de cálcio, bem maiores, no período de 30 dias do que no de 72 horas. As reações químicas que ocorrem entre as soluções de azul de metileno e produtos alcalinos também devem ser levadas em consideração.

As observações de MORAES ${ }^{*}$, corroboradas por este trabalho, de que durante o corte dos espécimes, para análise da infiltração marginal, se detectou a presença de azul de metileno no interior dos canais radiculares, mais especificamente, na massa obturadora com pasta de hidróxido de cálcio e que as paredes dos canais não se deixaram marcar pelo corante, deixa a certeza de que a infiltração ocorreu; contudo, ela não foi detectada porque a dentina não se deixou marcar por ela ou algo o impediu de acontecer. A neutralização da ação marcadora do azul de metileno não deve ter ocorrido, visto que as extremidades das luvas que seguravam os espécimes durante o desgaste da dentina ficaram impregnadas (marcadas) pelo corante.

A simples obstrução física dos túbulos dentinários relatadas por $B E R G E N H O L T Z Z^{9}$ não parece ser suficiente para 
impedir a marcação da infiltração. Assim, provavelmente, deva acontecer algumas alterações químicas na parede dentinária, em maior ou menor profundidade, dependendo das condições de limpeza das paredes e que, talvez, pudessem ser as responsáveis pela não marcação da dentina, embora a infiltração tenha ocorrido, caracterizando assim, um resultado falso-negativo. PORKAEW ${ }^{70}$ relatou a formação de carbonato de cálcio que poderia provocar a menor infiltração. Outros autores demonstram, claramente, que 0 hidróxido de cálcio provoca a alcalinização da dentina ${ }^{21,62,78}$.

Assim, os resultados deste trabalho permitem concluir que, quando se usa o cimento de óxido de zinco e eugenol, o curativo com hidróxido de cálcio é benéfico e que, provavelmente, deve ocorrer uma interação dos resíduos do mesmo com 0 cimento obturador, provocando uma expansão e conseqüentemente, melhorando o selamento. A aplicação do EDTA antes do curativo com hidróxido de cálcio é importante, pois, deve eliminar a lama dentinária, permitindo assim, uma atuação mais intensa e direta do hidróxido de cálcio nas paredes dos canais radiculares, sobre uma dentina estruturada. Todavia, a reaplicação do EDTA após o curativo não é recomendada, pois os resultados não foram bons, levando-se a suspeitar de que 0 EDTA, aplicado nessas condições, possa eliminar o efeito benéfico do hidróxido de cálcio.

Após analisar-se tudo o que foi observado, escrito e deduzido, muitas dúvidas ainda restam quanto à real ação do hidróxido de cálcio sobre a marcação da infiltração marginal das 
soluções de azul de metileno, nas paredes dentinárias . O campo continua aberto para novas investigações visando elucidar essa problemática. 


\section{7 - CONCLUSÕES}




\section{7 - CONCLUSÕES}

A metodologia específica utilizada neste trabalho, a análise dos resultados e os cálculos estatísticos permitem concluir que:

a. em relação ao hidróxido de cálcio:

a1.o emprego do hidróxido de cálcio, tanto na forma de curativo, como na forma de pasta obturadora, demonstrou estatisticamente interferência na marcação da infiltração marginal, diminuindo a sua magnitude.

b.em relação ao EDTA:

b1. a aplicação do EDTA, anteriormente à colocação do curativo de hidróxido de cálcio, melhorou a qualidade do selamento em canais obturados com cimento de óxido de zinco e eugenol.

b2. a aplicação dupla do EDTA, antes e após o curativo com hidróxido de cálcio, propiciou um aumento na infiltração, em canais obturados com cimento de óxido de zinco e eugenol.

b3. em canais obturados com pasta de hidróxido de cálcio, empregada como cimento obturador, a aplicação do EDTA não promoveu interferências significativas nos resultados. 
REFERÊNCIAS BIBLIOGRÁFICAS 


\section{REFERÊNCIAS BIBLIOGRÁFICAS ${ }^{*}$}

1. AHLBERG,K.M.F.; ASSANANOP, P.; TAY, W.M.A. Comparison of the apical dye penetration patterns show by methylene blue and India ink in root-filled teeth. Int. Endod. J., v.28, n.1, p.30-4, Jan. 1995.

2. AKPATA, E.S.; BLECHMAN, H. Bacterial invasion of pulpal dentin wall in vitro. J. dent. Res., v.61, n.1, p.435-8, Feb. 1982.

3. ALEXANDER, J.B.; GORDON, M.T. A comparison of the seal apical produced by two calcium hydroxide sealers and a Grossman-type sealer when used with laterally condensed gutta-percha. Quintessence Int., v.16, n.9, p.615-21, Sept. 1985.

4. AL-GHANDI, W. Testing of sealing ability of endodontic filling materials. Endod. Dent. Traumatol., v.10, n.6, p.249-55, Dec. 1994.

5. AZUL de Metileno. In: FARMACOPÉIA dos Estados Unidos do Brasil. 2 ed. São Paulo, Siqueira, 1959. p.119-20.

\footnotetext{
"Normas recomendadas para uso no âmbito da Universidade de São Paulo, com base no documento "Referências Bibliográficas: exemplos", emanado do Conselho Supervisor do Sistema Integrado de Bibliotecas da USP, em reunião de 20 de setembro de 1990.
} 
6. BAKER, N. A. et al. Scanning electron microscopic study of efficacy of various irrigating solutions. J. Endod., v.1, n.4, p.127-35, Apr. 1975.

7. BARKHORDAR, R. A.; BUI, T.; WATANABE, L. Na evaluation of sealing ability of calcium hydroxide sealers. Oral Surg. Oral Med. Oral Pathol., v.68, n.1, p.88-92, July 1989.

8. BERBERT, A.; BRAMANTE, C.M.; BERNARDINELI, N. Endodontia prática. São Paulo, Sarvier, 1980.

9. BERGENHOLTZ, G.; REIT, C. Reactions of the dental pulp to microbial provocation of calium hydroxyde treated dentin. Scan. J. Dent. Res., v.88, n.33, p.187-92, 1980.

10.BONETTI FILHO, I.; LEAL, J.M.; MENDES, A.J.D. Avaliação in vitro da capacidade seladora de diferentes técnicas de obturação dos canais radiculares através da infiltração do corante Rhodamina B a 0,2\%. Rev. odont. clin., v.1, n.2, p.17-21, jan./jun. 1987.

11. BRAMANTE, C.M. et al. Técnica de condensação lateral para obturação de canais radiculares de pequenos diâmetros com cones de guta-percha. Estomat. Cult., v.6, n.1, p. 70-2, 1972. 
12. BRANCINI, M.R. Avaliação da eficiência de limpeza de algumas soluções irrigadoras sobre a dentina radicular. Através de microscopia eletrônica de varredura. Bauru, 1982. 103p. Dissertação (Mestrado). Faculdade de Odontologia de Bauru, Universidade de São Paulo.

13. BRANNSTRÖM, M.; NYBORGH, H. Cavity tretament with a microbiological fluoride solution: growth of bacteria and effect on the pulps. J. Prosth. Dent., v.30, n.3, p.303-10, Sept. 1973.

14. CALLERÓ, F.D.S. et al. Ação química do EDTA sobre a dentina do canal radicular - análise com espectofoto

15. CIUCCHI, B.; KHETTABI, M.; HOLZ. J. The effectiveness of diferent endodontic irrigation procedures on the removal of the smear layer. a scanning electron microscopic study. Int. Endod. J., v.22, n.1, p. 21-8, jan. 1989.

16. COOK, E.F.; MARTIN, E.W. Fármacia prática de Remington. 10. Ed., México, Union Tipográfica Editorial Hispano Americana, 1959. p.119-20.

17. DALAT, D.M.; SPANBGERB, L.S.W. Comparison of apical leakage in root canals obturated with various gutta-percha 
techniques using a dye vacium tracing method. J. Endod., v.20, n.7, p.315-9, July 1994.

18. DE DEUS, Q.D. Endodontia. 5. ed. Rio de Janeiro, Medsi, 1992. P.446, 453-4.

19. DIAMONT, A.; CARREL, R. The smear-layer: a review of restorative progress. J. Pedod., v.8, n.3, p.219-6, 1984.

20. EVANS, J.T.; SIMON, H. Evolution of the apical seal produced by injected termoplasticized gutta-percha in the absence of smear layer and root canal sealer. J. Endod., v.12, n.3, p.101-7, Mar. 1986.

21. FAVA, L.R.G. Efeito antibacteriano das paredes de hidróxido de cálcio. Revisão. Rev. paul. Odont., v.15, n.1, p.10-6, jan./feb. 1993.

22. FOSTER, K.H.; KULLID, J.C.; WELLER, R.N. Effect of smear layer removal on the diffusion of calcium hydroxide through radicular dentin. J. Endod., v.19, n.3, p.136-40, Mar. 1993.

23. GeTtLEMAN, B.H.; MESSER, H.H.; ELDeeb, M.E. Adhesión de los cementos selladores a la dentina con y sin barro dentinário. Endodoncia, v.9, n.2, p.29-37, abr./jun. 1991. 
24. GOLDBERG, F.; ABRAMOVICH, A. Analysis of the effect of EDTAC on the dentinal walls of the root canal. J. Endod., v.3, n.3, p.101-5, Mar. 1997.

25. GOLDBERG, F.; MASSONE, E.; SPIELBERG, C. Estudio comparativo de la acción del EDTAC y el salvisol sobre la pared del conducto radicular instrumentado. Analises con microscopia eletrônica de barrido. Rev. esp. Endod., v.2, n.1, p.17-20, mayo 1984.

26. GOLDBERG, $F$. et al. Analysis of the effect of thylenediaminetetraacetic acid on the apical seal of root canal fillings. J. Endod., v.11, n.12, p.544-7, Dec. 1985.

27. GOLDMAN, M. et al. The efficacy of several endodontic irrigating solutions: a scanning electron microscopic study: part 2. J. Endod., v.8, n.11, p.487-92, Nov. 1982.

28. GOMES, I.C. et al. Diffusion of calcium through dentin. J. Endod., v.22, n.11, p.590-5, Nov. 1996.

29. HIZAGATU, R. et al. Estudo dos efeitos de instrumentação do canal radicular em três diferentes técnicas através da microscopia eletrônica de varredura. Rev. bras. Odont., v.44, n.4, p.10-6, jul./ago. 1987. 
30. HOLLAND, R, et al. Efeitos de diferentes preparados àbase de EDTA na dentina de canais radiculares. Rev. Fac. Odont. Araçatuba., v.2, n.1, p.127-31, 1973.

31. HOLLAND, R. et al. Avaliação da eficiência do selamento marginal de obturações de canal. Influência de variáveis introduzidas no método da condensação lateral. Rev. gaúcha Odont., v.23, n.4, p.247-52, 1975.

32. HOLLAND, R. et al. Reaction periapical tissue to pulp extirpation and inmediate root canal filling with calcium hydroxide. J. Endod., v.3, n.2, p.63-7, Feb. 1977.

33. HOLLAND, $R$. et al. The effect of calcium hydroxide in dentine. Rev. Fac. Odont. Araçatuba., v.7, n.2, p.177-83, 1978.

34. HOLLAND, R. et al. Influência de soluções descalcificadoras na obturação do sistema de canais radiculares. Rev. bras. Odont., v.45, n.2, p.16-22, Mar. 1988.

35. HOLLAND, R. et al. Influência de alguns procedimentos clínicos na infiltração marginal de obturações realizadas pela técnica de condensação lateral. Rev. Paulista de Odontologia, v.13, n.4, p.29-38, jul./ago. 1991. 
36. HOLLAND, $R$. et al. Infiltração marginal dos cimentos endodônticos. Rev. Gaúcha Odont., v.39, n.6, p.413-6, nov./dez. 1991.

37. HOLLAND, R.; MURATA, S.S. Efeito do hidróxido de cálcio como curativo de demora no selamento marginal após obturação de canal. Rev. Ass. paul. cirurg. Dent., v.47, n.6, p.1203-7, nov./dez. 1993.

38. HOLLAND, R, et al. Endodontia. Araçatuba, Faculdade de Odontologia de Araçatuba, 1993.

39. HOLLAND, R. et al. Infiltração marginal de hidróxido de cálcio como curativo de demora. Rev. odontol. UNESP, São Paulo, v.22, n.2, p.249-55, 1993.

40. HOLLAND, R.; MURATA, S.S.; SALIBA, O. Efeito a curto e médio prazos dos resíduos de hidróxido de cálcio na qualidade do selamento marginal após a obturação de canal. Rev. Paul. Odont., v.17, n.2, p.12-6, mar./abr. 1995. 
41. HOLLAND, R. et al. Apical leakage following root canal dressing with calcium hydroxide. Endod. Dent. Traumatol., v.11, p.261-3, 1995.

42. HOLLAND, R. et al. Apical leakage after root canal filling with na experimental calcium hydroxide gutta-percha root. $\mathbf{J}$. Endod., v.22, n.2, p.71-3, Feb. 1996.

43. HOLLAND, R. et al. Análise do selamento marginal obtido com cimentos a base de hidróxido de cálcio. Rev. Ass. paul. cirurg. Dent., v.50, n.1, p.61-4, jan./feb. 1996.

44. INGLE, J.J. A standardized endodontic technique utilizing newly designed instruments and filling materials. Oral Surg. Oral Medicine Oral Pathology., v.14, n.1, p.8391, Jan. 1961.

45. ISHLEY, D.; EL Deeb, M. An in vitro assesment of the quality of apical seal of termomechanically obturated canals with and without sealer. J. Endod., v.9, n.6, p.242-5, June 1983.

46. KAUFMAN, A. et al. New chemotherapeutic agent for root canal treatment. Oral Surg., v,46, n.2, p.283-95, Aug. 1978. 
47. KAUFMAN, A. et al. Life and AH26 as sealers in thermetically compacted gutta-percha root canal fillings: leakage too a dye. J. Endod., v.15, n.2, p.68-71, Feb. 1989.

48. KHOURI DIEP, E. Ação da limpeza sobre as paredes dos condutos radiculares de diferentes formulações e técnicas de aplicação de EDTA (Análise em microscópio eletrônico de varredura). Bauru, 1992. 143 p. Dissertação (Mestrado) - Faculdade de Odontologia de Bauru, Universidade de São Paulo.

49. KONTAKIOTIS, E.G.; WU, M.K.; WESSELINK, P.R. Effect of calcium hydroxide dressing on seal permanent root filling. Endod. Dent. Traumatol., v.13, n.6, p.281-4, Dec.1997.

50. LIMKANGMALMONGKOL, S. et al. A comparactive study of the apical leakage of four root canal. J. Endod., v.17, n.10, p.495-9, Oct. 1991.

51. LUCAS, V. Incompatibilidades medicamentosas. Rio de Janeiro, J.R. de Oliveira, 1932. p.82.

52. MADER, C.L.; BAUMGARTNER, J.C.; PETERS, D.D. Scanning electron microscopic investigation of the smeared layer on root canal walls. J. Endod., v.10, n.10, p.477-83, Oct. 1984. 
53. MADISON, S.; KREEL, K.V. Comparison of ethylenediamine tetracetic acid and sodium hypoclorite on the apical seal endodontically treated teeth. J. Endod., v.10, n.10, p.499-503, Oct. 1984.

54. MALTOS, S.M.M. et al. Avaliação in vitro do selamento apical por infiltração de corante azul-de-metileno e aspecto radiográfico das obturações dos canais radiculares e molares. Revista do CROMG, v.2, n.2, p.103-7, jul./dez. 1996.

55. MARGELOS, J. et al. Interation of calcium hydroxide with zinco oxide-eugenol type sealers: a potential clinical problem. J. Endod., v.23, n.1, p.43-8, Jan. 1997.

56. MC COMB, D.; SMITH, D.C. A preliminary scanning electron microscopy study of root canals after endodontic procedures. J. Endod., v.1, n.7, p.238, July 1975.

57. MC COMB, D.; SMITH, D.C.; BEAGRIE, G.S. The results of in vivo endodontic chemomechanical instrumentation - a scanning electron microscopy study. J. Brit. Endod., v.9, n.1, p.11-8, 1976. 
58. METHYLENE BLUE. In: BUDAVARI, S. et al., eds. The Merck Index. 11. ed. Rahway, Merck, 1989. p.954.

59. MICHELICH, V.J.; SCHUSTER, G.S.; PASHLEY, D.H. Bacterial penetration of human dentin in vivo. J. dent. Res., v.59, n.8, p.1398-403, May./Aug. 1980.

60. MORAES, I.G. Infiltração marginal nas obturações de canais radiculares em função de agentes irrigadores e cimentos obturadores. Bauru, 1981. 114p. Dissertação (Mestrado). Faculdade de Odontologia de Bauru, Universidade de São Paulo.

61. MORAES, I.G. Propriedades físicas de cimentos epóxidos experimentais para obturação de canais radiculares baseados no AH26. Bauru, 1984. P.149. Tese (Doutorado). Faculdade de Odontologia de Bauru, Universidade de São Paulo.

62. $\mathrm{NERWICH}, \mathrm{A}$. et al. PH changes in root dentin over a 4 week period following root canal dressing with calcium hydroxide. J. Endod., v.19, n.6, p.302-6, June 1993.

63. OLGART, L.; BRANNSTRÖM, M.; JOHNSON, G. Invasion of bacteria into dentinal tubules. Experiments in vivo and in 
vitro. Acta Odontol. Scandinavia, v.32, n.1, p.391-5, Nov. 1974.

64. OLIVEIRA, M.R.; LIA, R.C. Eficiência de limpeza de soluções irrigadoras empregadoras na biomecânica de canais radiculares (Instrumentação manual e combinação manual/ultra-sônica). Rev. Odont. Unesp., v.12, n.1/2, p.1-20, 1989.

65. ÖSTBY, B.N. Chelation in root canal therapy. Ethylenediamine tetra-acetic for cleansing and widening of root canals. Odont. Tidskr, v.65, n.2, p.3-11, Feb. 1957.

66. ÖSTBY, B.N. Seis años de experiencia clínica y experimental con el ácido etileno-diaminotetracético (EDTA) como coadyvante en la terapia de los condutos radiculares. Rev. Ass. Odont. Arg., v.50, n.76-81, feb. 1962.

67. PATTERSON, S.S. In vivo and in vitro studies of the effects of the dissodium salt of ethylenediamine tetra-acetic on human dentine and its endodontic implications. Oral Surg., v.16, n.1, p.83-103, Jan. 1963. 
68. PITT FORD, T.R.; ROBERTS, G.J. Tissue response to glass ionomer retrograde root fillings. Int. Endod. J., v.23, n.5, p. 233-8, Sept. 1990.

69. POLLARD, B.K.; WELLER, R.N.; KULLID, J.C. A standardized technique for linear dye leakage studies inmediate versus delayed imersion tissues. Int. Endod. J., v.23, n.5, p.250-3, Sep. 1990.

70. PORKAEW, P. et al. Effects of calcium hydroxide paste as an intracanal medicament on apical seal. J. Endod., v.16, n.8, p.369-74, Aug. 1990. 
71. SANTOS, E. et al. Estudo comparativo de tres substâncias para la preparación del conducto radicular. In: Jornada de Endodoncia, México 1984 apud KHOURI DIEP, E. Ação da limpeza sobre as paredes dos condutos radiculares de diferentes formulações e técnicas de aplicação de EDTA (análise em Microscópio Eletrônico de Varredura). Bauru, 1992, p.44-5, Dissertação (Mestrado). Faculdade de Odontologia de Bauru, Universidade de São Paulo.

72. SEN, B.H.; WESSELINK, P.R.; TÜRKÜN, M. The smear layer: a phenomenon in root canal therapy. Int. Endod. J., v.28, n.3, p.141-8, May. 1995.

73. SILVEIRA, F.F. Efeito do tempo de ação do curativo de demora à base de hidróxido de cálcio, utilizado em canais radiculares de dentes de cães com lesão periapical crônica induzida. Análise histológica e microscópica. Arararquara, 1997. 218 p. Dissertação (Mestrado). Faculdade de Odontologia, Universidade Estadual Paulista.

74. SJÖGREN, U. et al. The antimicrobial effect of calcium hydroxide as a short-term intracanal dressing. Int. Endod. J., v.24, p.119-25, 1991. 
75. SLEDER, F.S.; LUDLOW, M. O.; BOHACEK, J.R. Long-term ability of a calcium hydroxide sealer. J. Endod., v.17, n.11, p.541-3, Nov. 1991.

76. SPANGBERG, L.S.W.; ACIERVO, T.G.; CHA, B. Y. Influence of entrapped air on the accuray of leakage studies using dye penetration method. J. Endod., v.15, n.11, p.548-51, Nov. 1989.

77. TAKAHASHI, G. et al. Periapical enviroment after applying $\mathrm{Ca}(\mathrm{OH})_{2}$ into root canals in vitro. J. dent. Res., v.75, p.52, 1996. Special issue. /Abstract n.76/

78. TRONSTAD, L. et al. PH changes in dental tissues after root canal filling with calcium hydroxide. J. Endod., v.7, n.1, p.17-21, jan. 1981.

79. VOJINOVIC, O.; NYBORGH, H. BRANNSTRÖM, M. Acid treatment of cavities under resin fillings: bacetrial growth in dentinal tubules and pulpal reactions. J. dent. Res., v.52, n.6, p.1189-93, Jul./Dec. 1973.

80. VON DER FEHR, F.; ÖSTBY, N. Effect of EDTAC and sulfuric acid on root canal dentine. Oral Surg., v.16, n.2, p.199-205, Feb. 1963. 
81. WAKABAYASHI, $\mathrm{H}$. et al. Effect of calcium hydroxide paste dressing on un instrumented root canal wall. J. Endod., v.21, n.11, p.543-5, Nov. 1995.

82. WALTON, R.E. Histologic evolution of different methods of enlarging the pulp canal space. J. Endod., v.2, n.10, p.304-11, Oct. 1976.

83. WILLIANS, S.; GOLDMAN, M. Penetrability of the smearedlayer by a strain of proteous vulgaris. J. Endod., v.11, n.9, p.385-8, Sept. 1985.

84. WU, M.K.; KONTAKIOTIS, E.G.; WESSELINK, P.R. Decoloration of $1 \%$ methylene blue solution in contact with dental filling materials. J. Dent., v.26, n.7, p.585-9, Sept. 1998.

85. YAMADA, R.S. et al. A scanning electron microscopic comparison of a high volume final flush with several irrigating solutions: part 3. J. Endod., v.9, n.4, p.137-42, Apr.1983. 
ABSTRACT 


\section{ABSTRACT}

With the objective of evaluate the influence of calcium hydroxide and EDTA in marginal infiltration of metilen blue $2 \%$ in root canals obturated by the laterally condensed technique, were used 188 central superior incisor human teeth. After they were instrumented and impatented, the 188 teeth were divided in 3 groups of 60 teeth each. Each group was divided in 2 subgroups and these were divided again in 2, resulting 12 subgroups with 15 teeth each, this way discribed: Group l: immediate obturation; in 30 teeth was applied EDTA for 3 minutes before obturation; and in the other 30 the obturation was done without application of EDTA. 30 teeth were obturated with zinc oxide and eugenol ciment and 30 were obturated with calcium hydroxide paste; Group II: application of EDTA for 3 minutes and all root canals were filled with calcium hydroxide paste (bandage). In 30 teeth the EDTA was applied again after removing the bandage, but this was not done in the other 30; 30 teeth were obturated with calcium hydroxide paste; Group III: the root canals were filled with calcium hydroxide paste (bandage), without a previous application of EDTA, after they were instrumented. After removing the bandage, the EDTA was applied in 30 teeth one more time but not the other $30 ; 30$ teeth were obturated with zinc oxide and eugenol ciment and the other 30 with calcium hydroxide paste. After the immersion in metilen blue $2 \%$ for 72 hours, all the 180 teeth were longitudinally sectionalized and the infiltrations were measured using a stereomicroscope and a micrometric ocular. Statistics tests were done and according with 
those, the following conclusions were obtained: - calcium hydroxide: As a bandage and as an obturation paste, interferes in the infiltration; its use as a bandage, before obturation, with zinc oxide and eugenol ciment, improves the sealer quality of this last one; - EDTA: Its use before the calcium hydroxide bandage, improves obturation sealings with zinc oxide and eugenol ciment. It use after and before the bandage promotis an infiltration increasing in obturated root canals with zinc oxide and eugenol ciment; in root canals obturated with calcium hydroxide paste, the use of EDTA does not promote significative interferences in the result. 